\title{
Yapılarda Atık Yönetimi: Bir Eğitim Yapısı Üzerinden Geri Dönüşüm Önerileri ve Karbon Salımının Engellenmesi
}

\author{
Feride Çiğdem KARA ${ }^{1}$, Merve TUNA KAYILI ${ }^{2 *}$ \\ ${ }^{1}$ Karabük Üniversitesi, Lisansüstü Eğitim Enstitüsü, Mimarlık Anabilim Dal1,78600, Karabük \\ 2* Karabük Üniversitesi, Mimarlık Fakültesi, Mimarlık Bölümü,78600, Karabük
}

\section{Öz}

Enerji ve kaynak kullanımında büyük miktarda payı olan yapılara yaşam döngüsü boyunca yüksek hızda kaynak girdisi sağlanmakta ve hizmet ömrünün dolduğu yıkım sonrası evrede ise yapı bileşenlerinin geri kazanılmasına yönelik atık yönetimi etkin bir şekilde planlanmadığında enerji ve kaynak girdisi, ekolojik ve ekonomik kayıplara neden olmaktadır. Özellikle günümüzde kentsel dönüşüme uğrayan yapıların artması bu sorunu daha da öne çıkarmaktadır. Bu bağlamda, yapıya giren enerji ve kaynakların korunması ve geri dönüşümüne yönelik, Karabük'te yıkımı gerçekleştirilen bir eğitim yapısı üzerinden atık yönetiminin incelendiği çalışmada, yapılan literatür taraması sonucunda atık sahalarına gönderilen büyük miktardaki tuğla ve seramik atıklarının geri dönüşümüne yönelik öneriler belirlenmiştir. Sunulan bu geri dönüşüm önerileri sonucunda doğaya salımı engellenebilecek gömülü karbon miktarı tespit edilmiştir. Tuğla için 220 ton $601 \mathrm{kgCO}_{2}$ eq, seramik için ise 8 ton $41 \mathrm{~kg} \mathrm{CO} 2$ eq'nin doğaya salımının engellenebileceği tespit edilen yıkıntı atıklarının öneriler dahilinde sektöre kazandırılmasının, enerji ve kaynak korunumu açısından önemi belirtilmiştir.

Anahtar Kelimeler: Atık yönetimi, geri dönüşüm önerileri, tuğla, seramik, eğitim yapısı.

\section{Waste Management in Buildings: Recycling Suggestions and Prevention of Carbon Emission Through an Education Building}

\begin{abstract}
High-speed resource input is provided throughout the life cycle of the buildings that have a large share in energy and resource use. In the post-demolition phase where the service life of the buildings is over, when waste management for the recovery of building components is not planned effectively, energy and resource inputs cause ecological and economic losses. Especially today, the increase in buildings undergoing urban transformation puts this problem forward. In this context, the waste management of an education building demolished in Karabük for the protection and recycling of energy and resources included in the study was examined. As a result of the literature review, suggestions for the recycling of large amounts of brick and ceramic wastes sent to landfills were determined. As a result of these recycling suggestions, the amount of embodied carbon that could be prevented from being released into the environment was determined. The importance of recycling the wreckage wastes, which are determined to prevent the carbon emission of 220 tons of $601 \mathrm{~kg} \mathrm{CO}_{2}$ eq for bricks and 8 tons of $41 \mathrm{~kg} \mathrm{CO}$ eq for ceramics, to the sector within the scope of the recommendations, has been stated in terms of energy and resource conservation.
\end{abstract}

Keywords: Waste management, recycling proposals, brick, ceramics, education building. 


\section{Giriş}

İçinde yaşadığımız dünyada çevre sorunları ve etkileri giderek artmaktadır. 19. yy. da gerçekleşen sanayi devriminden sonra, kentlerin düzeni etkilenmiş, kırsal yerleşmelerden kentlere doğru göçler başlamıştır. İnşaat sektörü sanayi devriminden sonra hız kazanmış ve çevreye verdiği zararlar, doğanın kendi kendini iyileştiremeyeceği seviyelere ulaşmıştır. Hızla artan nüfus, beraberinde yapılaşmayı getirmiş ve yapılaşma yeni üretimlerle birlikte yüksek oranda kaynak tüketimine neden olmuştur. Bununla birlikte çevrenin korunması ve gelecek kuşaklara bozulmadan aktarılması için “sürdürülebilirlik” kavramı gündeme taşınmıştır (Sev, 2009) Böylece yapılardaki malzeme seçimi ve kullanımının önemi üzerinde çalışmalar yapılmaya başlanmıştır.

Yapılar, malzeme kaynaklarının \%30'unu, enerji kaynaklarının \%40’ını tüketmekle birlikte $\mathrm{CO}_{2}$ salımının da \%35'inden sorumlu tutulmaktadır (European Commission Energy Department, 2020). Bu nedenle kaynak tüketiminin kontrol altına alınması için yapısal atıkların değerlendirilmesi oldukça önemlidir.

Yapının yaşam döngüsü dört evreden oluşmaktadır. Bunlar; yapım öncesi, yapım, kullanım ve dönüştürme evresidir. Yapım öncesi evre, yapı malzemelerinin üretilebilmesi için hammaddelerin çıkarılması, işlenmesi, taşınması aşamalarını içermektedir (Şekil 1). Yapım ve kullanım evresi ise yapının inşa edilmesi ve sonrasındaki işletim, bakım, onarım evrelerini kapsamaktadır. Yıkım sonrası evre ise kullanım ömrünü tamamlamış yapı eleman ve bileşenlerinin yeniden kullanım, geri dönüşüm gibi atık yöntemlerini ele almaktadır (Soysal, 2008). Etkin atık yönetimi planlanmayan kullanım ömrünü tamamlamış yapılarda, yapısal atıkların doğaya bırakılması hem kaynak israfına hem de büyük bir çevre kirliliğine neden olmaktadır. Öyle ki, kentsel katı atıkların \% \% 30 ’luk kısmını inşaat atıkları oluşturmaktadır (Ölmez ve Yıldız, 2008). Ayrıca dünyada oluşan katı atıkların \%50'sinden inşaat sektörü sorumlu tutulmaktadır (Maçin ve Demir, 2018). Bu katı atıkların içinde beton, çelik, tuğla, alçı, ahşap, cam, metal, plastik ve hafriyat toprağı gibi malzemeler önemli oranda yer tutmaktadır (Fırat ve Akbaş, 2015). Ayrıca geri dönüşüme uygun malzemelerin, dönüşüm seçenekleri yerine, hammadde kullanımı ile birincil malzemelerden üretimi malzeme ve enerji kaynaklarının tükenmesini hızlandırmaktadır. $\mathrm{Bu}$ nedenle yapı sektöründeki kaynak ve enerji tüketiminin azaltılması için yıkım sonrası evrenin yani yapı atık yönetiminin doğru planlanması oldukça önemlidir. Yıkım sonrasında malzemelerin geri dönüşümü ve tekrar kullanımı sırasında, malzeme akış döngüsü yeniden başlamakta ve bu döngüdeki işlem miktarı ne kadar az ise tüketilen kaynak ve enerji miktarı da o denli az olmaktadır (Yüksek ve Mihlayanlar, 2015). Bu döngünün yıkım sonrası evresinde dönüşüm yöntemleri irdelendiğinde, en kısa yolun yeniden kullanım yöntemi olduğu görülebilmektedir (Şekil 1). Yapı malzemelerinin yeniden kullanılması önemli miktarda enerji ve hammadde kazancı sağlayabilmektedir. Geri dönüşüm yöntemi ise ayrıştırma, kırma, ufalama gibi ek işlemler gerektirebilmekte ve malzeme ve ürünlerin sahip olduğu ve ilk üretimden kaynaklanan toplam enerji miktarının da korunmasını sağlamaktadır. Geri dönüşüm için gerekli enerji miktarı, ilk üretim için harcananın genellikle çok altında olabilmektedir (Aydın İpekçi vd., 2017).

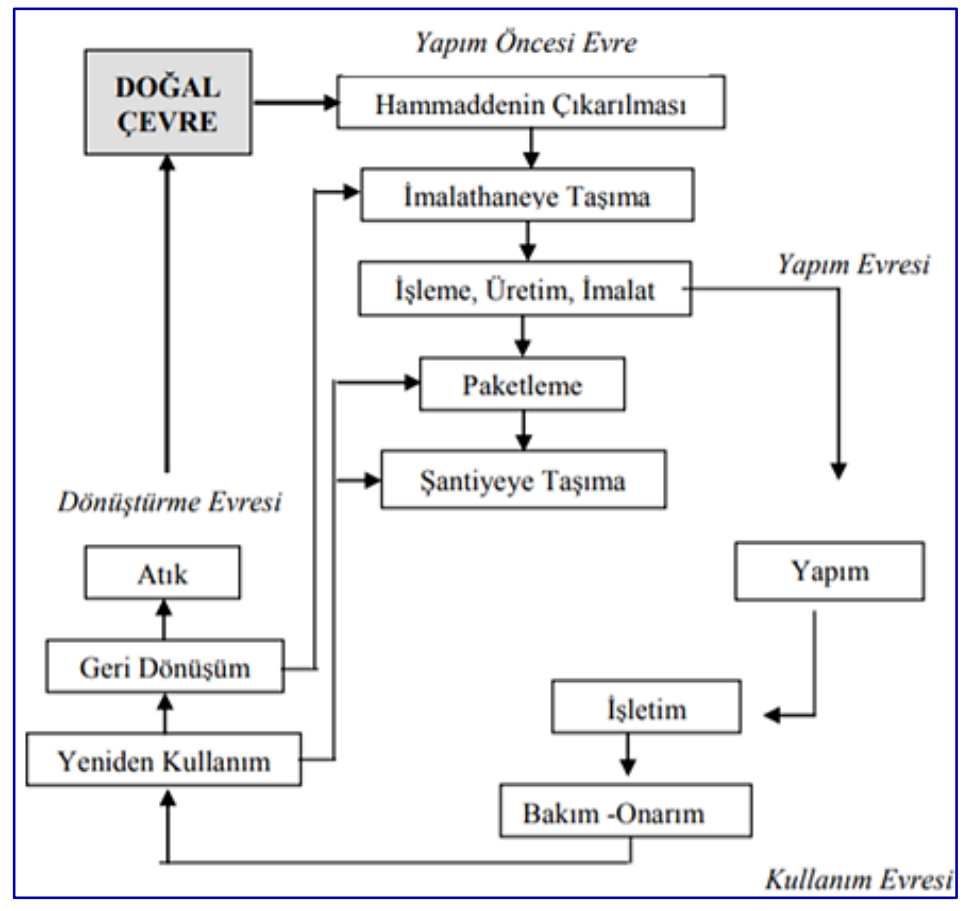

Şekil 1. Yaşam döngüsü değerlendirme kapsamında yapı ömrü (Soysal, 2008). 
Atık yöntemlerinde ise geri dönüşümden sonra gelen bir diğer yöntem ise enerji kazanımı bağlamında ele alınabilecek yakma işlemidir. Fakat bu yöntemde yakma esnasında çevreye zarar verebilecek salımlar açığa çıkabilmekte, hava kirliliğine neden olabilmektedir. Ayrıca yakma ile kazanılan enerji, geri dönüşüm ve yeniden kullanım ile karşılaştırıldığından oldukça düşük olmaktadır (Sabbas et al., 2003). Yapı malzemelerinin atık olarak depolanması ise tercih edilmemesi gereken yöntemdir (Şekil 2).

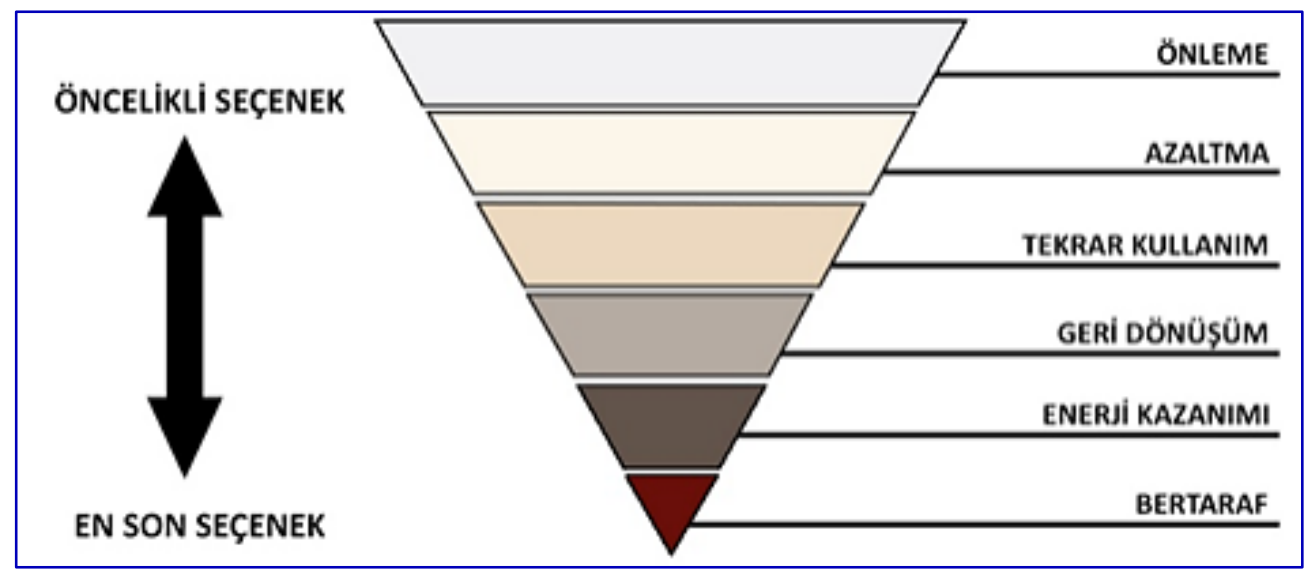

Şekil 2. Atık yönetim hiyerarşisi (URL-1).

Yapısal atıklar; inşaat atıkları, onarım atıkları ve yıkım atıkları olarak sınıflandırılabilmektedir. İnşaat atıkları genellikle yapım evresinde ortaya çıkan, kullanılamayan artık malzemelerden oluşan, üzerinde kalıntı bulundurmayan küçük parçalar halinde iken; yıkım atıkları ömrünü tamamlamış yapılardan ayrıştırılmadan ortaya çıkan üzerinde kalıntılar yer alan büyük parçalı atıklardır. (Al-Ansaryet al., 2004). Onarım atıkları ise inşaat ve yıkım malzemelerinin her ikisini de içeren atıklardır (Paker, 2017). Yıkım atıkları üzerlerinde kir, boya gibi kimyasal kalıntılar barındırsa bile $1 \mathrm{~m} 3$ atığın yaklaşı $0.60 \mathrm{~m} 3$ 'ünün geri dönüştürülebilir içeriğe sahip olduğu varsayılmaktadır (Kılıç, 2012). Bu oran yapısal atıkların büyük miktarlarda geri dönüştürülebilir olduğunu göstermektedir.

Türkiye'de yıkım üstlenicileri; yıkılan binalardan geri dönüşüme göndermek üzere öncelikli olarak demir, çelik, alüminyum, ahşap almayı hedeflemektedir. Bunlar yüksek kar getiren malzemeler oldukları için kurtarılması en çok tercih edilen malzemeler olmaktadır. Ülkemizde yıkım atıkları çoğunlukla; yıkım aşaması öncesi sökülen doğramalar, vitrifiyeler, mutfak dolapları, mutfak tezgâhları ve yer kaplamaları gibi yapı elemanlarının yeniden kullanımıyla veya betonarme inşaatların yıkımı sonrası demirlerin istiflenip demir-çelik fabrikalarına geri dönüşüm için gönderilmesi şeklinde değerlendirilmektedir (Buzkan ve Erman, 2019). Bir yapıdan çıkarılıp başka bir yapıda kullanılabilecek yapı ürünleri arasında kap1 ve pencere doğramaları, kiremit, alüminyum, bakır, galvanizli saç gibi çatı örtü malzemeleri, kiremit altı tahta veya panoları, çatı makasları, aşıklar ve mertekler, sıcak su tankları, pompalar, termostatlar, tesisat boruları, radyatörler, lavabo, küvet, duş kabinleri, musluklar, evyeler, mutfak tezgahları, dolaplar, yağmur olukları, yağmur iniş boruları sayılabilmektedir (Paker, 2017). Yıkım atıklarının yeniden kullanım ve geri dönüşümünün mümkün olabilmesi için yıkım öncesinde gerekli atık planlamasının yapılmalı ve uygun yıkım teknikleri ve söküm işlemleri gerçekleştirilmelidir (Tuna Kayılı et al., 2016). Ancak bu yolla etkin bir atık yönetimi ve atık dönüşümüne ulaşılabilecektir. Avrupa Birliği üyesi ülkelerin 2020 yılı için yıkıntı atıkları dönüşüm hedefi \%70 olarak belirtilmektedir (Atık Çerçeve Direktifi, 2008 (2008/98/EC). Ülkemizdeki atık miktarlarıyla ilgili verilerin yetersiz olması nedeniyle Avrupa ülkeleriyle kıyaslama yapmak mümkün olmamaktadır. Ülkemizde yapısal atıkların miktarına net olarak ulaşılamamakla birlikte yıllık yaklaşık 4 milyon ton atık üretilmektedir (Kotan, 2016). Son yıllarda artan kentsel dönüşüm projeleriyle bu miktarın artması beklenmektedir. İllere göre hafriyat ve yıkıntı atıkları Tablo 1'de sunulmuştur. $\mathrm{Bu}$ veriler daha çok yüksek hacimli inşaat faaliyetlerinin gerçekleştiği illerle sınırlı kalırken, düşük hacimli şehirlerin verilerine ulaşılamamaktadır.

Yapı malzemelerinin üretimi için gerekli olan oluşum enerjisi doğaya salınan karbon miktarı ile de doğru orantılıdır. Gömülü karbon değeri, oluşum enerjisinin yüksek ve düşük olmasına paralel olarak, yapı ürünlerinin üretimi sırasında açığa çıkan karbon değeri olarak tanımlanabilmektedir (Tuna Kayılı and Özmen, 2020). Yapı ürünü üretiminin artmasıyla birlikte fosil kaynak ve enerji tüketiminin artması $\mathrm{CO}_{2}$ salımını da arttırmaktadır. $\mathrm{CO}_{2}$ salımındaki bu artış iklim değişikliğinde önemli bir paya sahip olmaktadır. 2018 verilerine göre binalar $\mathrm{CO}_{2}$ salımının \%39'undan sorumlu tutulmaktadır (Robati et al., 2021). Bu değerin \%28'lik kısmı yapı işletim sırasında açığa çıkarken, \%11'lik kısmı ise malzeme üretimi sırasında açığa çıkmaktadır. Malzeme üretimi sırasında açığa 
çıkan $\mathrm{CO}_{2}$ oranının da ise taşıma ve nakliye işlemleri küçük bir paya sahiptir (Kumanayake and Luo, 2018). Bu veriler bağlamında bir malzemenin tekrar üretilmesi yerine yaşam ömrünü tamamlamış yapılardan geri dönüşüm ve yeniden kullanım yoluyla elde edilmesi, $\mathrm{CO}_{2}$ salımının azaltılması için oldukça önemli olmaktadır.

Tablo 1. İllere göre 2019 yılı hafriyat toprağı ve inşaat/yıkıntı atığı miktarı (URL-2).

\begin{tabular}{ll}
\hline İl & Inşaat/yıkıntı atı̆̆ ve hafriyat topră̆ $\left(\mathbf{m}^{3}\right)$ \\
\hline İstanbul & $28,484,605 \mathrm{~m}^{3}$ \\
Ankara & $19,938,419 \mathrm{~m}^{3}$ \\
Adana & $720,336 \mathrm{~m}^{3}$ \\
Konya & $528,612 \mathrm{~m}^{3}$ \\
Kastamonu & $139,720 \mathrm{~m}^{3}$ \\
Karabük & Veri yok \\
\hline
\end{tabular}

Bu bağlamda çalışma kapsamında, Türkiye'de yıkımı gerçekleştirilen bir yapı üzerinden atık yönetiminin değerlendirilmesi, atık sahalarına gönderilen yıkıntı atıklarının geri dönüşüm potansiyellerinin belirlenmesi ve geri dönüşümü ile ne kadar gömülü karbon salımının engellenebileceğinin tespiti amacı ile 2020 yılında depreme dayanıksız olması nedeniyle yıkımı gerçekleştirilen bir eğitim binasının yıkım sonrası evresi incelenmiştir. Yapının yıkım atıklarının hangi yöntemle dönüştürüldüğü, hangi malzemelerin depolama ya da bertaraf edilerek kullanım ömrünün sona erdirildiği bilgisi edinilerek, bu malzemelerin geri dönüşüm potansiyellerinin değerlendirildiği bu çalışmanın, yeni yıkım ve atık yönetimi planlamalarında mimar ve yıkım üstlenicilerine yol gösterici olması hedeflenmektedir.

\section{Materyal ve Metot}

\subsection{Materyal}

$\mathrm{Bu}$ çalışmada atık yönetimi incelenen eğitim yapısı, henüz yıkımı gerçekleştirilmiş bir yapı olması nedeniyle Karabük Fevzi Çakmak Ortaokulu olarak belirlenmiştir. Bu bölümde ise eğitim yapısının mimari özelliklerine ve yıkım hikayesine yer verilmiş, yapının yıkım evresinde geri dönüşüme gönderilmeyip atık sahalarına bırakılan yıkıntı atıklarının miktarına ve gömülü karbon emisyon değerlerine nasıl ulaşıldığına yönelik hesaplamalar açıklanmıştır.

\subsection{Metot}

Çalışmada 4 aşamadan bahsedilebilmektedir. Bu aşamalar;

1. Seçilen eğitim yapısının yıkımı sonrasında ortaya çıkan atık malzemelerin yıkım sonrası durumunun tespit edilmesi.

2. Atık malzemelerin yıkımı gerçekleştirilen eğitim yapısı üzerinden metrajlarının tespit edilmesi

3. Yıkım sonrası atık sahalarına nakledilen malzemeler için kapsamlı literatür taraması ile geri dönüşüm önerilerinin belirlenmesi

4. Atık sahalarına nakledilen bu malzemelerin geri dönüşümü ile önlenebilecek $\mathrm{CO}_{2}$ salım miktarının belirlenmesi şeklindedir.

Çalışma yöntemi akış şeması Şekil 3’te verilmiştir. 


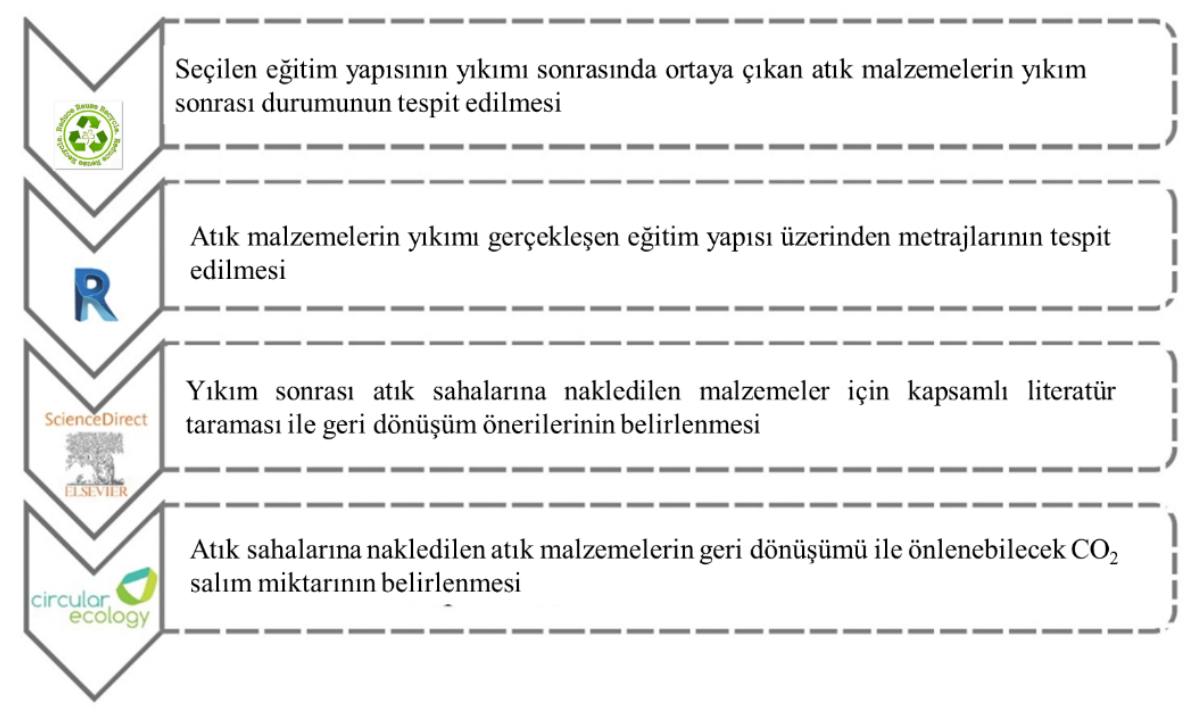

Şekil 3. Çalışma yöntemi akışı.

\subsection{Yapı Bilgileri ve Yıkım Hikayesi}

Fevzi Çakmak Ortaokulu yıkılmadan önce Karabük Merkez mahallelerinden Fevzi Çakmak Mahallesi'nde yer alan, 2 katlı, $666 \mathrm{~m}^{2}$ taban alanına sahip bir eğitim yapısıdır. Toplamda ise $1329 \mathrm{~m} 2$ inşaat alanına sahip (Şekil 4) (İyican, 2016) yığgma eğitim yapısı 1967 yılında inşa edilmiş olup (Şekil 5), 2020 yılında gerçekleştirilen incelemede yapının depreme dayanıksız olduğu tespit edilmiştir. Bu nedenle eğitim yapısının 2020 yılında yıkım kararı alınmış ve yıkım işi 2020 yılının Haziran ayında Açık Teklif Usulü ile hurda karşılığı yıkım işi gerçekleştirilmiştir (URL-3).

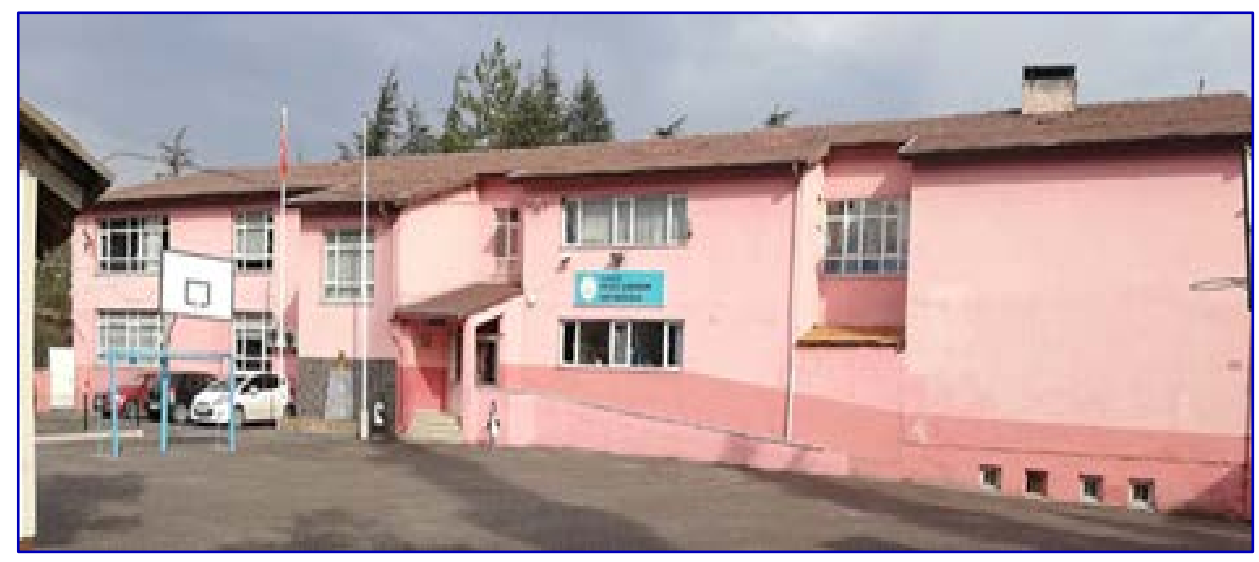

Şekil 4. Eğitim yapısı 2020 yılı görünüşü (URL-4).

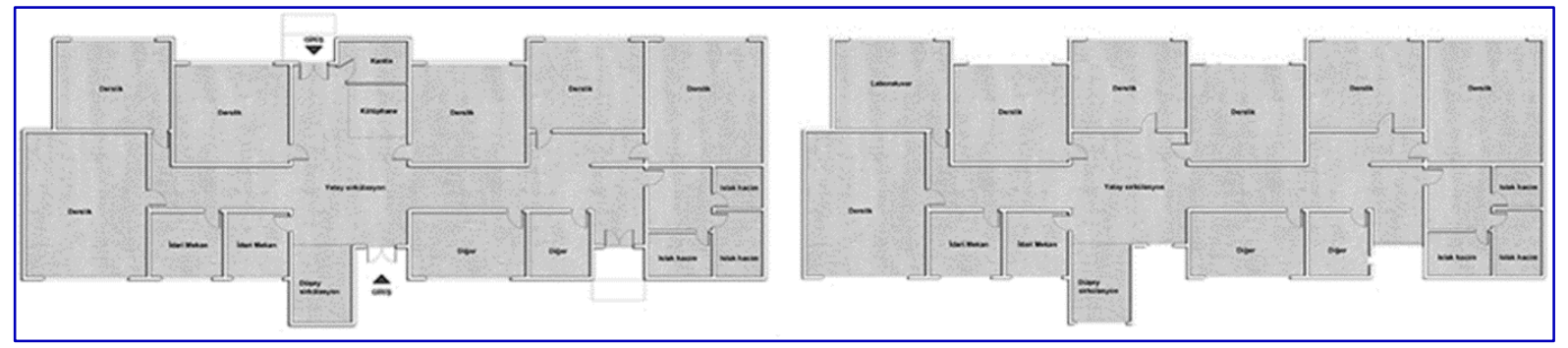

Şekil 5. Eğitim yapısı şematik kat planları (İyican, 2016).

Okul yönetiminden alınan bilgiler doğrultusunda yapının yıkım süreci tespit edilmiştir. Elde edilen bilgilere göre yıkım öncesi taşınır donatı malzemeleri Milli Eğitim Bakanlığı'na ait depolara, gerektiğinde yeniden kullanımı için nakledilmiştir. Yapının kapı, pencere, çatı konstrüksiyonu, radyatör, elektrik kablosu gibi malzemeleri 
yeniden kullanım ve geri dönüşüm için sökülmüş olup depolara gönderilmiştir. Yapı malzemelerinin büyük kısmını oluşturan tuğla ve zemin kaplama malzemesi olan seramikler ise yıkım sonrasında atık olarak nakledilmiştir (Tablo 2).

Tablo 2. Eğitim yapısı yıkım sonrası atık yönetimi.

\begin{tabular}{|c|c|c|c|}
\hline \multirow{2}{*}{$\begin{array}{l}\text { Yıkıntı atıkları } \\
\text { Tuğla }\end{array}$} & \multicolumn{3}{|c|}{$\begin{array}{l}\text { Yıkım sonrası durumu } \\
\text { Atık - Yeniden Kullanım - Geri Dönüșüm }\end{array}$} \\
\hline & $\mathrm{x}$ & O & $\circ$ \\
\hline Seramik zemin kaplama malzemesi & $\mathrm{x}$ & ○ & $\circ$ \\
\hline Kapı & $\circ$ & $\mathrm{x}$ & $\circ$ \\
\hline Pencere doğramaları & o & $\mathrm{x}$ & $\circ$ \\
\hline Cam & $\circ$ & $\mathrm{x}$ & $\circ$ \\
\hline Kiremit & ○ & $\mathrm{x}$ & $\circ$ \\
\hline Kalas (Çatı) & ○ & $\mathrm{x}$ & $\circ$ \\
\hline Radyatörler ve boruları & ○ & ○ & $\mathrm{x}$ \\
\hline Elektrik kabloları & ○ & O & $\mathrm{x}$ \\
\hline Taşınır donatılar & $\mathrm{O}$ & $\mathrm{x}$ & $\circ$ \\
\hline
\end{tabular}

\subsection{Yıkıntı Atıkları İçin Geri Dönüşüm Önerilerinin Belirlenmesi}

Bölüm 2.1'de verilen Tablo 2'de görülebileceği gibi, eğitim yapısının yıkım evresinde birçok malzeme için yeniden kullanım ve geri dönüşüm yöntemleri seçilmişken, tuğla ve seramik yıkıntı atıkları atık sahalarına gönderilmiştir. Bu bağlamda, çalışma kapsamında tuğla ve seramik atıklarının yapıda yeniden kullanım yöntemleri ve buna bağlı olarak yapılan çalışmalar ile ilgili kapsamlı bir literatür taraması ile araştırılıp, öneriler sunulmuştur.

\subsection{Yıkıntı Atıklarının Gömülü Karbon Değerinin Belirlenmesi}

İncelenen eğitim yapısında depolama sahalarına atık olarak gönderilen tuğla ve seramiğin geri dönüşüme gönderilmesi ile yeni kaynak kullanımının önüne geçilerek ne kadar gömülü karbon salımının engellenebileceği ICE DB V3.0 (Inventory of Carbon and Energy) (URL-5) veri tabanı ve Eşitlik 1 kullanılarak hesaplanmıştır. ICE İngiltere'de mevcut oluşum enerjisi ve gömülü karbon verileri seçilerek oluşturulan, açık kaynak olarak ulaşılabilen veri tabanlarından biri olmasıyla bilinmektedir. Gömülü karbon değerlerinin belirlenmesinde GABI, Ecoinvent gibi veri tabanları da bulunmakla birlikte, bu veri tabanları açık kaynak olarak kullanılamamaktadır. Seçilen malzemelerin özellikleri ve veri niteliği Tablo 3 'te verilmiştir. Malzemelerin veri tabanındaki özellikleri ile atık malzemelerin ağırlık olarak benzeşmesi esas alınmıştır. Tuğla ve seramik atıklarına yönelik metrajlar Revit Architecture programı yardımıyla tespit edilmiş, malzemelerin veri tabanından alınan birim kg gömülü karbon değerine ait verilerle Eş.1 kullanılarak her atık malzeme için toplam gömülü karbon değerine ulaşılmıştır.

$$
\Sigma G K D=m \times \mathrm{gkd}
$$

Burada;

¿GKD: Toplam gömülü karbon değeri ( $\left.\mathrm{kg} \mathrm{CO}_{2} \mathrm{eq}\right)$

m: Kütle (kg)

gkd: Birim gömülü karbon değeri $\left(\mathrm{kg} \mathrm{CO}_{2} \mathrm{eq}\right)$

Tablo 3. Malzemelerin birim gömülü karbon değerleri (ICE DB V3.0).

\begin{tabular}{llll}
\hline Malzeme & $\begin{array}{l}\text { Birim Ă̆ırlığı } \\
(\mathbf{k g})\end{array}$ & $\begin{array}{l}\text { Birim Gömülü Karbon } \\
\text { Değeri } \mathbf{( k g ~ C O} \mathbf{~} \mathbf{e q})\end{array}$ & Tanım \\
\hline Tuğla & 2.13 & 0.45 & $\begin{array}{l}\text { Ortalama bir adet İngiltere tuğlasının } \\
\text { ağırlığı 2.13kg'dır. }\end{array}$ \\
Seramik & 3.54 & 0.48 & $\begin{array}{l}\text { Genel basit pişmiş kil ürünler (pişmiş } \\
\text { toprak ve tuğla dahil) }\end{array}$ \\
\hline
\end{tabular}




\section{Bulgular}

İncelenen Fevzi Çakmak Ortaokulu yapısında kullanılan malzeme miktarının önemli bir kısmını oluşturan tuğla $\left(1393 \mathrm{~m}^{2}\right)$ ve seramik $\left(960 \mathrm{~m}^{2}\right)$ yıkıntı atıklarının, depolama sahalarına gönderildiği tespit edilmiştir. Bu bölümde yapının yıkım süreci sonunda ortaya çıkan atık miktarları ve geri kazanım yöntemleri ile atık sahalarına gönderilen malzemeler için geri dönüşüm önerilerine yer verilmiştir. Ek olarak bu malzemelerin atık sahalarına gönderilmeyip, geri dönüşüm yöntemi ile kazanılması sonucunda yeni kaynak kullanımının önüne geçilmesiyle birlikte salımının engellenebileceği gömülü karbon miktarı tespit edilmiştir.

\subsection{Yapı Yıkım Süreci ve Atık Miktarları}

Yapının yıkım kararının alınmasıyla ilk olarak taşınır donatılar yeniden kullanılmak üzere depolara götürüldüğü, ardından yeniden kullanılması için kapı, pencere, çatı konstrüksiyonunu oluşturan malzeme ve kiremitlerin; radyatörler, elektrik kabloları gibi hurda değeri yüksek malzemelerin yapıdan sökülerek yeniden kullanım için değerlendirildiği bilgisine ulaşılmıştır. Bu malzemelerin yeniden kullanımı ve geri dönüşümü ile kaynak ve enerji tasarrufu sağlandığı açıktır. Yapının büyük bir kısmını oluşturan (\%66) duvar malzemesi tuğla ve yer kaplama malzemesi seramik ise yıkıntı atığı olarak döküm sahalarına boşaltılmıştır (Tablo 4 ve Şekil 6). Bu yaklaşımda da görüldüğü gibi yapı atıklarına yaklaşım, hurda değeri yüksek olan malzemelere ve yeniden kullanımı yaygın olan malzemelere yöneliktir. Yapıda ihmal edilemeyecek miktarlarda olan malzemeler ise atık sahalarına gönderilmesi de kaynak kullanımının azaltılması açısından büyük bir sorun teşkil etmektedir.

Tablo 4. Y1kıntı atıkları ve miktarları.

\begin{tabular}{lll}
\hline Yıkıntı atıkları & Atıkların Değerlendirilme & Miktarı $\left.\mathbf{( m}^{\mathbf{2}}\right)$ \\
\hline Kiremit & Yöntemi & \\
Kapı & Yeniden Kullanım & 667 \\
Cam & Yeniden Kullanım & 208 \\
PVC Doğrama & Yeniden Kullanım & 270 \\
Tuğla & Yeniden Kullanım & 50 \\
Seramik & Atık sahasına nakledilmesi & 1393 \\
\hline
\end{tabular}

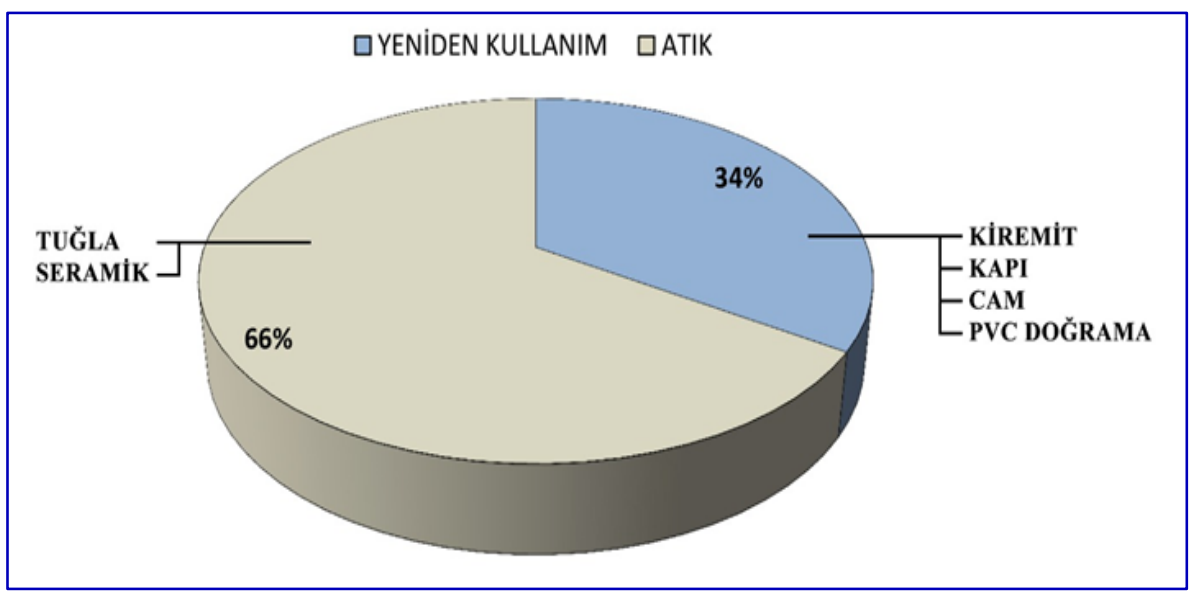

Şekil 6. Y1kım sonrası yapı malzemelerinin durumu.

\subsection{Tuğla Atıkları İçin Geri Dönüşüm Önerileri}

Tuğla atıklarının doğaya bırakılması çevre kirliliğine sebep olurken, atık sahasına bırakılması ya da atık depolarında bekletilmesi, geri dönüşüme gönderilmeyen her kaynak için yeni bir kaynak ihtiyacını doğurmaktadır. $\mathrm{Bu}$ nedenle hizmet ömrünü dolduran yapı malzemelerinin yeniden kullanımı ya da geri dönüşümü, enerji ve kaynak korunumu açısından önemlidir.

Atık tuğlalar kırma ve ayrıştırma gibi ön işlemlerin ardından kolaylıkla yapı sektörüne kazandırılabilmektedir. Atık tuğlaların geri dönüştürülmesi üzerine Bangladeş’te yapılan bir çalışmada, ilk öneri kırık tuğlaların çimentolu 
bir harca katılıp bloklar oluşturulması ve bu blokların peyzaj tasarımında zemin karosu olarak kullanılmasıdır. İkinci öneri ise kırık tuğlaların ögütülüp tekrar tuğla hammaddesi olarak kullanılması şeklindedir. Buna ek olarak sunulan üçüncü öneride ise asfalta katkı malzemesi olarak kullanılması önerilmiştir. Çalışma Bangladeş’te kırsal yolların ancak \%27,4’ünün asfalt kaplı olduğunu, kalan kısmının yakın gelecekte asfaltlanacağını belirterek, atık tuğlaların asfalta katkı maddesi olarak kullanılmasının yol bütçesinden \%13,96 tasarruf sağlayacağının altını çizmektedir (Islam et al., 2019).

Tuğla atıkları iri agrega olarak kaldırım taşı ve parke yapımında kullanılabilmektedir. Buna yönelik bir çalışmada, tuğla agrega katkılı beton parke bloğu yapmanın mümkün olduğu ortaya konulmuştur (Şekil 7) (Jankovic, et al., 2012).

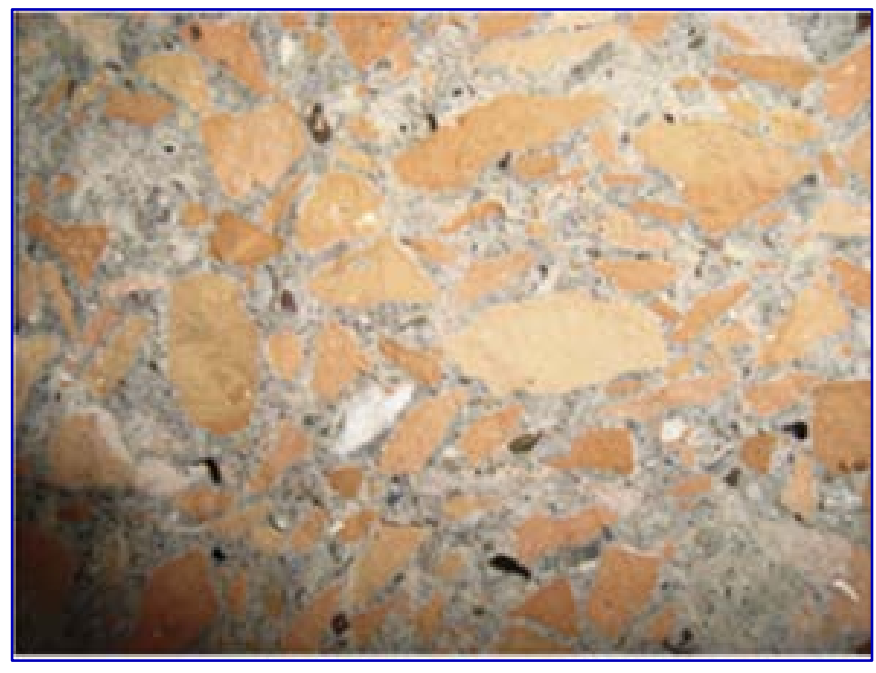

Şekil 7. Tuğla agrega katkılı beton parke (Jankovic et al., 2012).

Poon ve Chan (2006) çalışmasında kaldırım bloklarına ezilmiş tuğla atığı (Şekil 8) eklenmesinin, bloklarının yoğunluğunun, basınç dayanımının ve gerilme mukavemetinin azalmasına neden olsa da \%50 kırılmış tuğla kullanılan kaldırım bloklarının minimum gereksinimleri karşıladığını ortaya koymuştur. Hong Kong'da yapıllmış bu çalışmada trafiğin yoğun olduğu alanlarda kullanılan blokların ise $\% 25$ kırılmış tuğla katkısı ile üretiminin mümkün olabileceği belirtilmiştir (Poon and Chan, 2006a).

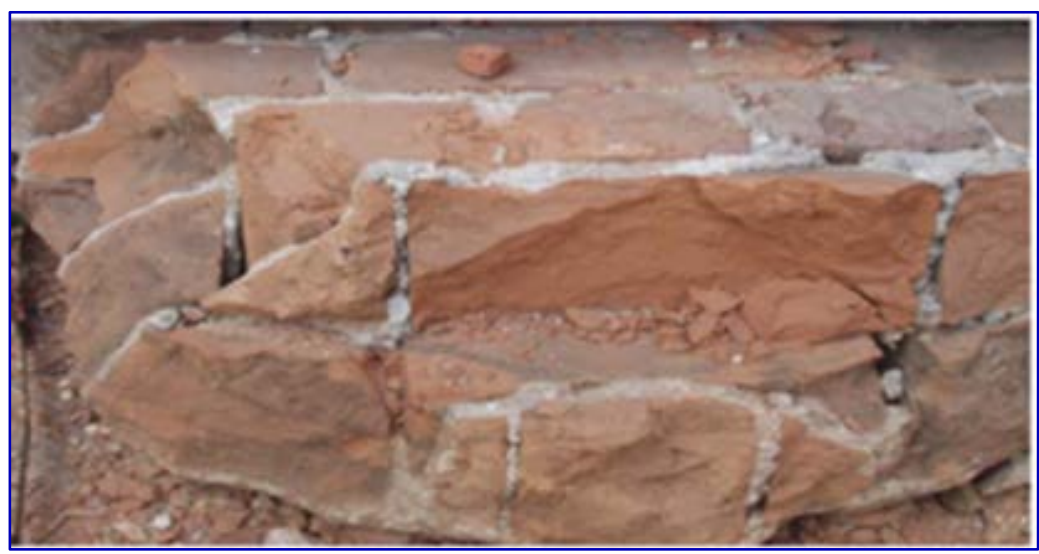

Şekil 8. Kaldırım bloğu yapımında kullanılan atık tuğla (Poon and Chan, 2006a).

Tuğlanın ince veya iri agrega olarak betonla birlikte kullanılması durumunda, betonun basınç dayanımını düşmektedir. Bunun ana nedeni tuğlanın killi ve gözenekli olmasıdır (Bolouri Bazaz and Khayati, 2012). Ancak tuğla kırılıp agrega olarak kullanıldığında donma-çözünme testlerinde yüksek performans gösterebilmektedir. Tuğlanın killi ve yüksek gözenekli yapısından dolayı yüksek geçirgenlik derecesi ve hafifliği tuğlanın avantajlarındandır. Ayrıca tuğla agrega yüksek geçirgenliğe sahip olmasına rağmen tuğla agregayla hazırlanmış betonun geçirgenliği düşük olmaktadır (Bolouri Bazaz and Khayati, 2012). Buna rağmen, Saleem vd.'nin yaptığ1 bir çalışma, tuğla agregalı betona bakteri eklenerek, kendi kendini iyileştiren beton üzerinedir. Bu çalışmanın bir 
diğer amacı da, kaldırım betonlarında oluşan çatlaklardan yabancı maddelerin içeriye sızmasıyla, zamanla beton dayanımının düşmesinin engellenmesidir. Çalışmada bakteriler, iyileştirici ajan olarak; tuğla agrega ise durdurucu olarak nitelendirilmiştir. Tuğla agreganın tercih edilme sebebi doğal agregaya göre absorbe yeteneğinin fazla olmasıdır. Böylece bakterileri hareketsiz hale getirmek mümkün olmuştur. Çalışmada betona eklenen atık tuğla miktarı arttıkça, beton dayanımın azaldığı görülmesine rağmen, tuğlanın bakteri sporlarıyla uyumlu bir malzeme olduğu belirtilmiştir (Şekil 9). En iyi beton iyileşme sonucunun \%50 atık tuğla katkılı betonun belirtildiği bu çalışma, düşük dayanıma uygun betonlarda atık tuğla ve bakteri ile yenilikçi bir malzeme üretilebileceğini ortaya koymuştur (Saleem et al., 2021).

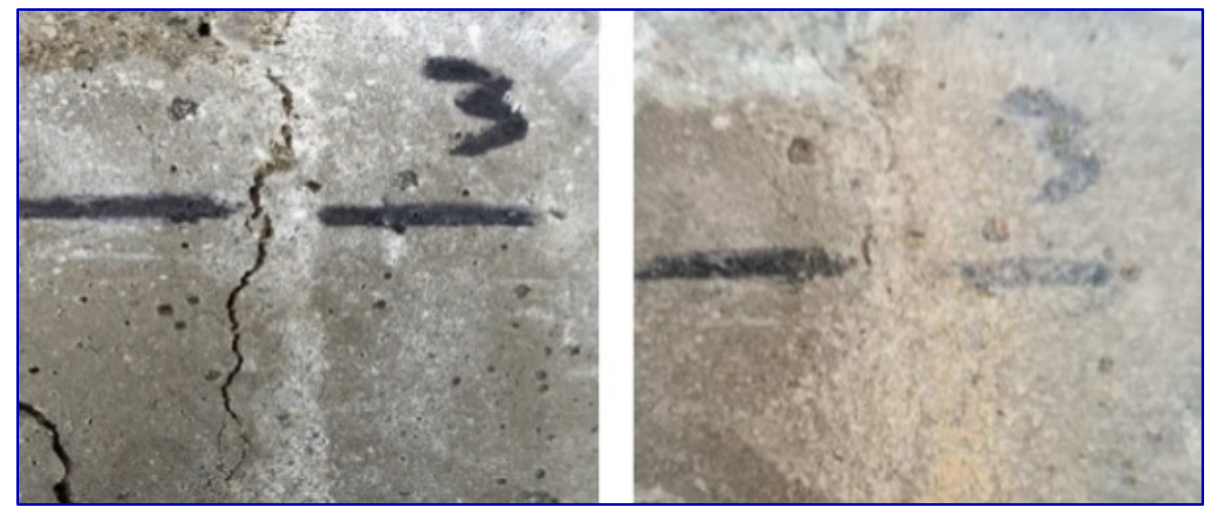

Şekil 9. Atık tuğla katkılı betonda gözlenen iyileşme (Saleem et al., 2021).

İnce agrega olarak öğütülen atık tuğla çimentoya katkı maddesi olarak kullanılabilmektedir. Fakat dikkat edilmesi gereken husus tuğla atığının tanecik boyutudur. Tanecik boyutu hazırlanan harcın özelliklerini etkilemektedir. Ma vd. (2020) yaptığı çalışmada, atık tuğla parçacık boyutlarının işlenebilirliğe ve mekanik performansa etkisini incelemiş̧tir. Numunelerin işlenebilirliğini ve mekanik performansını ortaya koymak için su emilimi, basınç dayanımı, eğilme dayanımı ve kuruma büzülmesi belirlenmiş ve tuğla agreganın inceliği arttıkça puzolanik özelliğin arttığ1 görülmüştür. Ancak tuğla tozu oranı \% 15’ten fazla ve boyutu çimento inceliği kadar ve/veya daha ince olduğunda ise basınç dayanımının azaldığı görülmüştür (Ma et al., 2020). Tuğla tozu katkılı harç üzerine bir diğer çalışma da Bektas vd.(2009)'nin tuğla tozunun harç dayanıklılığına etkisi üzerine bir çalışmadır. Doğal agrega yerine ağırlıķa \%10 ve \%20 oranlarında ezilmiş tuğla agrega eklenmiştir. Elde edilen sonuçlarda tuğla oranı arttıkça harç akışkanlığının azaldığı görülmüştür. İki numunede de harcın basınç dayanımı üzerine tuğlanın olumsuz etkisi olmadığı gözlenmiş ancak harç büzülmesinde sınırlı etkisi olduğu ortaya konulmuştur. Tuğlanın, harcın donma-çözülme performansına olumlu etki ettiği belirlenmiştir (Bektas et al., 2009).

Tuğla tozunun harca katılmasıyla birlikte donatıya etkisinin belirlendiği tez çalışmasında ise tuğla tozu, çimento ağırlığının \%0’dan 40’a kadar çimento harcına eklenmiştir. Mekanik özellikleri yeterli görülen \%5, 15, 30, 40 oranlarında tuğla tozu içeren harçlarla korozyon etkisini ölçmek için donatılı numuneler oluşturulmuştur. Yapılan incelemelerde, tuğla tozu ikamesinin artmasıyla korozyon etkisinin arttığ1 görülmüştür. \%5’lik numunenin referans örnekle benzer sonuçlar verdiği, \%15'lik numunenin ise korozyon dayanımının en yüksek olduğu ortaya konulmuştur (Dalkılıç, 2004). Tuğla katkı maddesi ile hazırlanmış harçların macun dolguda kullanıldığı çalışmada, portland çimentosu yerine atık tuğla tozu ilave edildiğinde dayanımın arttığı görülmüştür. Ancak tuğla tozu oranının \%15'i geçtiğinde ilave arttıkça dayanımın azaldığı ve kullanılan tuğlanın cinsinin de dayanım üzerinde etkili olduğu belirtilmiştir (Külekçi, 2013). Tuğla tozunun çimento yerine harçlarda kullanılması da oldukça önemsenmiştir. Çünkü çimentonun çevre kirliliği ve enerji tüketimi üzerindeki etkileri oldukça fazladır. Ortega vd. (2018) çimentonun \%20'si kadar ilave edilen tuğla tozuyla oluşturulan harcın mikro yapısı, dayanıklılığı ve mekanik özelliklerini 400 güne kadar analiz etmiş, tuğla tozunun puzolanik etkisini doğrulamıştır. Çalışmada tuğla tozunun harçlarda basınç kaybına neden olmadığı, \%10 ve \%20 tuğla tozu içeren harçların uzun vadede portland çimentosuyla yapılan harçlara göre daha iyi hizmet verdiği belirtilmiştir (Ortega et al., 2018).

Atık tuğla tozunun mineral dolgu ile birlikte asfalta eklenmesi, asfaltın mekanik dayanımını artırmaktadır. Bu bağlamda yapılan bir çalışmada, tuğla dolgunun asfaltta kalıcı deformasyonu azaltabileceği ve daha iyi tekerlek izi direnci sağlayabileceği belirtilmiştir (Chen et al., 2011). Tuğla kırıklarının asfaltta agrega ağırlığının \%50'si oranında kullanılması durumunda deformasyonu azalttığı ve yüksek dayanımların gerekmediği yol inşaatlarında kullanılabileceği belirtilmektedir. Deformasyon miktarının azalması daha uzun süre $\neg$ kullanılabilecek yollar sağlamaktadır. Tuğla kırıklarının yüzey şekillerinin agregaya göre daha kırıklı olması ve tuğlanın gözenekli yapısı sayesinde yaz aylarında asfalta meydana gelen kusma olayı da engellenmiş olmaktadır (Şekil 10) (Çakar, 2009). 


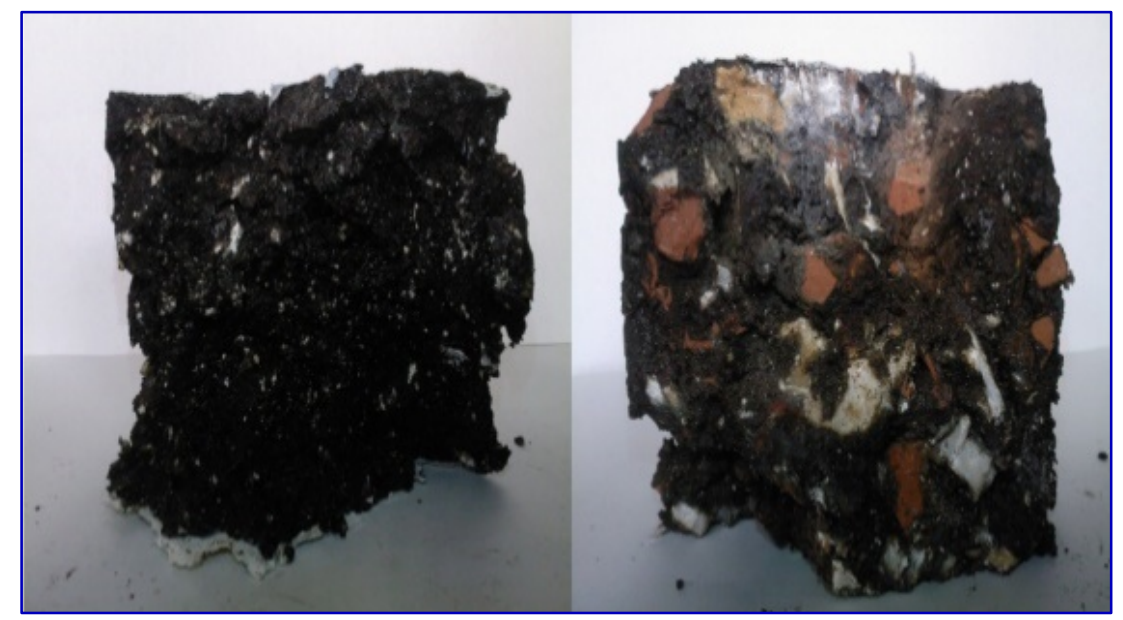

Şekil 10. Asfaltta kullanıla tuğla agrega (Çakar, 2009).

Tuğla atıklarının yol alt temel uygulamalarında kullanılması da söz konusudur. Hong Kong'da 2005'te yapılan bir çalışmada beton agregalarla ezilmiş kil tuğla agrega alt temel malzemesi olarak geri dönüştürülmüş beton agrega ile karıştırılmış ve tuğlanın optimum nemin arttırdığı, kuru yoğunluğu ise azalttığı görülmüşsür. Ayrıca tuğla agreganın kullanıldığı numunenin nem değişikliklerine daha az duyarlı olduğu belirtilmiştir (Poon and Chan, 2006b). Tuğla agreganın yol temel alt tabanında doğal agrega ile birlikte kullanılmasında tuğlanın iyileştirici etkisi olduğu, tuğla agreganın $\% 25$ oranında doğal agrega ile oluşturulduğu, üç katman doğal agrega ve iki katman tuğla kombinasyonunun en uygun kombinasyon olduğu belirtilmiştir. Malzemenin kontrolsüz ve düzensiz dağılımının taşıyıcılığı azalttığı buna bağlı olarak malzemenin karıştııllarak uygulanması yerine kademeli harman modeli ile uygulanması önerilmiş̧tir. Yol alt temelinde tuğla agreganın kullanılması durumunda bağlanmamış tabakada kullanılması ve doğal agrega ile birlikte kullanılması istenmiştir (Abed and Mahdi, 2018). Ayrıca atık tuğla ile geri dönüştürülmüş asfaltın birlikte kullanıldığı bir çalışmada, bu malzemelere uçucu kül eklenmiş ve uçucu külün dayanımı arttırdığı gözlenmiştir. Bu durumda geri dönüştürülmüş tuğla ve asfaltın performansının uçucu kül sayesinde arttırılabileceği söylenebilmektedir (Mohammadinia et al., 2017).

Tuğla tozunun kendiliğinden yerleşebilen betona eklendiği çalışmada, tuğla tozunun köşeli ve pürüzlü yapısının harcın su gereksinimini artırdığ 1 ve tuğla tozunun viskozite dengeleyici olarak kullanılabileceği öne sürülmüştür. Ayrıca tuğla tozunun silis içeriği hidratasyon reaksiyonunu hızlandırmakta ve erken dayanımın artmasına katkı sağladığı belirtilmiştir. Tuğla tozunun kendiliğinden yerleşen betonda kullanılması ile ayrışma önleyici etkisinden faydalanılabileceği fakat tuğla tozunun \%20'lik orandan fazla kullanıldığı durumlarda yerleşme boşluklarının meydana geldiği belirtilmiştir. Bu sonuç numunelerin dayanımını olumsuz etkileyeceği için kullanıldığı oran oldukça önemlidir (Açıkgenç, 2009).

Tuğlanın betonda ince ve iri agrega olarak kullanımı mümkündür. Ancak kullanım oranı önemlidir. İri agrega için sınır \%25, ince agrega için ise \%50'dir (Debieb and Kenai, 2008). Yapılan çalışmalarda tuğlanın betonda agrega olarak kullanılabileceği, fakat belirli sınırlarda olması ve özellikle inşaat atığı olan tuğlanın betona katkısı durumunda daha dikkatli olunması gerektiği belirtilmektedir (Debieb and Kenai, 2008; Cachim, 2009, 2021). Çünkü atık tuğlanın türü ve içeriği betonun davranışını etkilemekte, önceden doyurulduklarında betonun kendi kendini kürlemesine yardım edebilmekte fakat kırılmış tuğlaların miktarı arttı̆̆ında, bu avantaj tuğlaların gözenekliliğindeki artı̧̧ tarafından geçersiz kılınıp ve kötü sonuçlara yol açabilmektedir (Cachim, 2009). Ayrıca beton içerisindeki tuğla agreganın, betondaki alkalilerle reaksiyonu da söz konusu olabilmektedir (Bektaş, 2014). Tuğlanın iri agrega olarak betona eklenmesi sık yapılan çalışmalar olup buna ek olarak lif eklenerek yapılan çalışmalar (Zhang et al., 2020; Meza andSiddique, 2019, 2021) daha yenidir. İnşaat atıklarından toplanan iri tuğla agrega ile üretilmiş betona lif ekleyerek (Şekil 11) tuğla agregalı elyaf takviyeli betonun davranışlarının belirlenmesi amacıyla yapılan çalışmada, tuğla agreganın betona eklenmesi basınç ve gerilme dayanımını önemli ölçüde düşürse de lif eklentisi bu sorunu gidermekte etkili olmuştur. Ayrıca tuğla agreganın su gereksinimini arttırması liflerin eklenmesiyle kontrol altında tutulabilmiştir. Elde edilen sonuçlar, tuğla agreganın betona eklenmesiyle ortaya çıkan olumsuz performans özelliklerinin, lif eklentisi ile kontrol altına alınabileceğini göstermektedir (Zhang et al., 2020). 


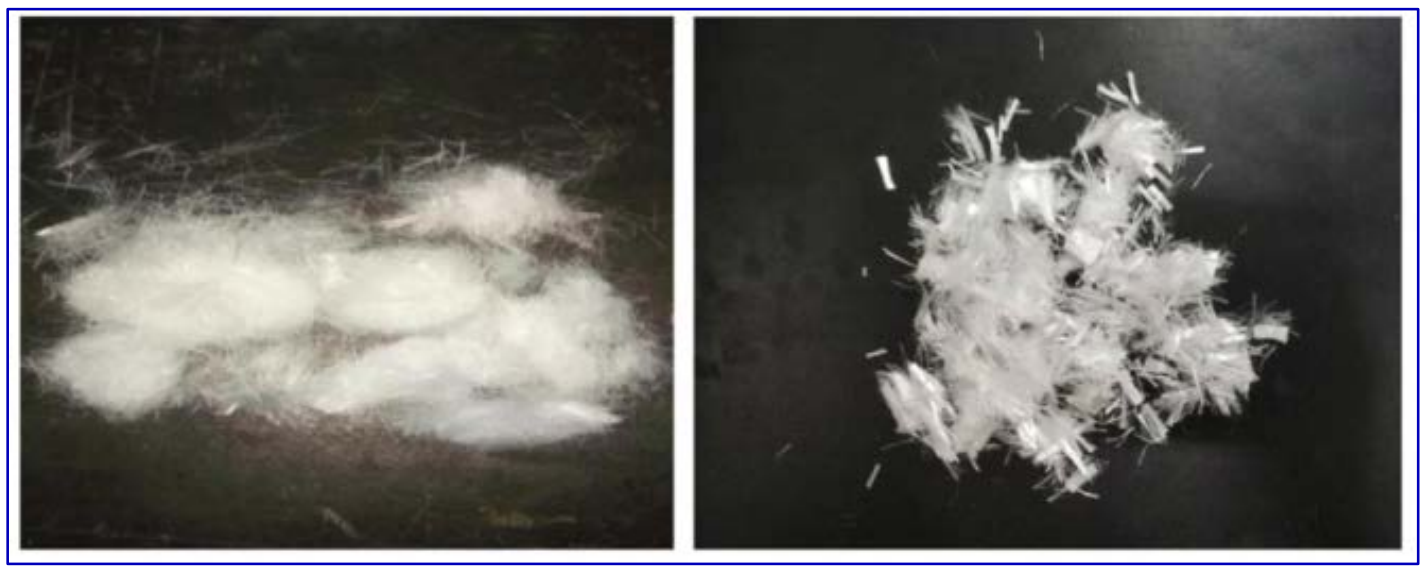

Şekil 11. Betona eklenen elyaf (Zhang et al., 2020).

Tuğla atıklarının bir diğer kullanım alanı ise öğütülüp tekrar tuğla üretiminde hammaddeye eklenmesidir. Çorum ilinde tuğla üretimi sırasında açığa çıkan atık tuğlaların yeniden üretime katılmasının amaçlandığı çalışmada tuğla atıkları toz haline getirildikten sonra farklı eleklerden geçirilerek kaba ve ince olmak üzere ikiye ayrılmıştır. Bu tozlar kütlece \%0, 10, 20, 30 oranlarında ham tuğla kiline eklenmiştir. Karışıma atık eklenmesi rötreyi azaltmış, atık tuğla içeriğinin artması dayanıklılığın azalmasına sebep olmuştur. Atık ilavesi arttıkça su emilimi de artmış fakat bu durum pişirme sıcaklığının arttırılmasıyla giderilebilmiştir. Pişirme sıcaklığı dayanımın istenilen düzeye getirilmesinde de etkili olmuş ve en ekonomik pişirme sıcaklığının $900^{\circ} \mathrm{C}$ olduğu tespit edilmiştir. Hem kaba hem ince tuğla kullanımı, karışımın plastisitesini düşürmüş olup, bu bağlamda en uygun atık tuğla kullanımı oranı \%30, atık boyutu ise ince atık olarak belirlenmiştir (Demir and Orhan, 2003).

Atık tuğlanın yeniden tuğla üretiminde kullanılması için başka bir atıkla birleştirilmesi de söz konusudur. Endüstriyel atıkların geri kazanımı amacıyla yapılan tuğla atığının öğütülmüş granüle yüksek firın cürufu ile birleştirilerek jeopolimer tuğla üretiminin gerçekleştirildiği çalışmalarda jeopolimer tuğlanın fiziksel ve mekanik özelliklerinin iyileştirildiği gözlenmiştir. En yüksek basınç dayanımının \%40 atık tuğla \%60 ögütülmüş granüle yüksek fırın cürufundan oluşan jeopolimer numunesinde kaydedilmesi ve dayanım değerinin geleneksel jeopolimer tuğlanın dayanımının altı katı olması, geleneksel tuğlalara alternatif çevre dostu tuğla üretiminin bu şekilde yapılabileceğini ortaya koymuştur (Youssef et al., 2019; Zawrah et al., 2016).

Tuğlanın geri dönüşümü için bir diğer öneri ise, kırmızı dekoratif sıva üretiminde kullanılmasıdır. 2016 yılında yapılan çalışmada dekoratif sıvalar; tuğla tozu, çimento, kum karışımıyla hazırlanmış, hazırlanan farklı sıvaların renkleri, performansları ve su emme seviyeleri incelenmiştir. Elde edilen sonuçlarda sıvanın istenilen renk düzeyini sağladığı ve suya dayanımında ise büyük bir değişiklik görülmediği belirtilmiştir. Sıvanın basınç ve eğilme dayanımının ise iyileştirilebilecek düzeyde olduğu sonucuna ulaşılmıştır. Elde edilen sonuçlar geri dönüştürülmüş tuğla tozunun dekoratif sıva yapımında kullanılabileceğini ortaya koymaktadır (Li et al, 2016).

Tuğlanın geri dönüşümünün enerji etkin bir şekilde gerçekleştirilmesi de önemli bir konudur. Oluşum enerjisini aşan bir geri dönüşüm yöntemi, atık azaltımı açısından anlamlı iken, gömülü karbon değerinin azaltılması bakımından anlamsız kalabilmektedir. Bu bağlamda yapılan çalışmada, en yaygın kullanılan üç atık tuğla geri dönüşüm yöntemini çevresel etkilerine göre kıyaslanmıştır. Çalışmada ele alınan üç yöntem tuğlanın doğal agrega ile değiştirilmesi, kısmi olarak çimento ile değiştirilmesi ve toplam çimento miktarı ile değiştirilmesi olarak sayılabilmektedir. Geri dönüştürülmüş agrega senaryosu toplama, taşıma, ayırma, ezme ve öğütme gibi adımlar içermektedir. Çalışma sonucunda; geri dönüştürülmüş agrega senaryosu en düşük çevresel etkiye neden olurken, $\mathrm{CO}_{2}$ salımında dikkate değer fayda sağlamadığı belirlenmiştir. Kısmi çimento katkı maddesi olarak kullanımı ise önemli çevresel faydalar sağlamış ve sınırlı olumsuz sonuçlarla en uygun seçeneği temsil etmiştir. Çimento ile yer değişiminde ise minimum karbon salınımı tespit edilmiş ancak insan sağlığına olumsuz etkileri gözlenmiştir (Fort and Cerny, 2020).

Yukarıda incelenen çalışmalar bağlamında atık tuğlaların kaldırım taşı ve parke yapımında, çimento katkı maddesi ve betona katk1 olarak, yol alt temel malzemesi ve asfaltta katkı maddesi olarak, macun dolguda, yeniden tuğla üretim sürecinde ve dekoratif sıva üretiminde kullanılabileceği sonucuna ulaşılmıştır. Bu öneriler için uygun tane boyutları Tablo 5'te verilmiştir. Eğitim yapısında geri dönüşüm yerine atık sahalarına terkedilen tuğla atıkları için bu öneriler kolaylıkla uygulanabilecek durumdadır. 
Tablo 5. Atık tuğla için geri dönüşüm önerileri.

\begin{tabular}{|c|c|c|}
\hline Geri dönüşüm önerisi & Boyutu & Çalışmalar \\
\hline $\begin{array}{l}\text { Kaldırım bloklarında } \\
\text { kullanımı }\end{array}$ & İri agrega & (Jankovic et al., 2012), (Poon and Chan, 2006a) \\
\hline $\begin{array}{l}\text { Çimento katkı maddesi olarak } \\
\text { kullanımı }\end{array}$ & İnce agrega & $\begin{array}{l}\text { (Ma et al., 2020), (Ortega et al., 2018), (Fort and } \\
\text { Cerny, 2020) }\end{array}$ \\
\hline $\begin{array}{l}\text { Harç katkı maddesi olarak } \\
\text { kullanımı }\end{array}$ & İnce agrega & (Bektas et al., 2009), (Dalkılıç, 2004) \\
\hline Betonda kullanımı & $\begin{array}{l}\text { İri ve ince } \\
\text { agrega }\end{array}$ & $\begin{array}{l}\text { (Bolouri Bazaz and Khayati, 2012), (Saleem et al., } \\
\text { 2021), (Debieb and Kenai, 2008), (Cachim, 2009), } \\
\text { (Bektaş, 2014) }\end{array}$ \\
\hline Lifli betonda kullanımı & İri agrega & (Zhang et al., 2020), (Meza and Siddique, 2019) \\
\hline $\begin{array}{l}\text { Kendiliğinden yerleşebilen } \\
\text { betonda kullanımı }\end{array}$ & İnce agrega & (Açıkgenç, 2009) \\
\hline $\begin{array}{l}\text { Yol alt temel malzemesi } \\
\text { olarak kullanımı }\end{array}$ & İri agrega & $\begin{array}{l}\text { (Poon and Chan, 2006b), (Abed and Mahdi, 2018), } \\
\text { (Mohammadinia et al., 2017) }\end{array}$ \\
\hline Asfaltta kullanımı & $\begin{array}{l}\text { İri ve ince } \\
\text { agrega }\end{array}$ & $\begin{array}{l}\text { (Islam et al., 2019), (Chen et al., 2011), (Çakar, } \\
\text { 2009) }\end{array}$ \\
\hline $\begin{array}{l}\text { Yeniden tuğla üretiminde } \\
\text { hammadde olarak kullanımı }\end{array}$ & İnce agrega & $\begin{array}{l}\text { (Demir and Orhan, 2003), (Youssef et al., 2019), } \\
\text { (Zawrah et al., 2016) }\end{array}$ \\
\hline $\begin{array}{l}\text { Dekoratif sıva üretiminde } \\
\text { kullanımı }\end{array}$ & İnce agrega & (Li et al., 2016) \\
\hline Macun dolguda kullanımı & İnce agrega & (Külekçi, 2013) \\
\hline
\end{tabular}

\subsection{Seramik Atıkları İçin Geri Dönüşüm Önerileri}

Seramik atıklarının doğaya bırakılması çevre kirliliğine sebep olurken, atık sahasında ya da atık depolarında bekletilmesi yüksek 1Sı ile üretilen seramiklerin, buna bağlı olarak ortaya çıkan sera gazı salımlarının yeni üretimlerle artması anlamına gelmektedir. Bu nedenle hizmet ömrünü dolduran yap1 malzemelerinin yeniden kullanımı ya da geri dönüşümü, enerji ve kaynak korunumu açısından önemlidir.

Atık seramikler toz haline getirilip belirli oranlarda çimento yerine kullanılabilmektedir. Çimentoya eklenerek maliyetlerinin düşürülmesi hedeflenen bir çalışmada, portland çimentosuna seramik tozu eklenmiş ve harç üzerine etkisini belirlemek üzere numunelerin fiziksel, kimyasal ve mekanik özellikleri değerlendirilmiştir. Yapılan deneylerle seramik tozunun puzolanik özelliği kanıtlanmış ve \%35 oranına kadar çimentoya katılabileceği belirtilmiştir (Ünal, 1998). Seramik tozunun çimentoya ikamesinin etkilerini araştıran başka bir çalışmada ise bu oran \%40 olarak belirlenmiştir (Hasanah et al., 2018). Seramik tozunun çimentoya ikamesiyle ilgili bir diğer çalışmada ise, seramik tozunun boşluklu yapısından ötürü harcın kıvam suyunu arttırdığı ve priz süresinin uzamasına yol açtığı görülmüştür. Seramik tozunun \%10 oranında kullanıldığında taze harç özelliklerini iyileştirdiği ancak \%15 oranında kullanıldığında ise olumsuz sonuçlar verdiği tespit edilmiştir (Kalınçimen vd., 2015).

Seramik tozuyla hazırlanan sürdürülebilir harçların özelliklerinin iyileştirilmesi için uçucu kül de kullanılabilmektedir. Yapılan bir çalışmada sürdürülebilir harçlarda atık seramik tozunun yanı sıra kullanılan yüksek fırın cürufu yerine uçucu kül kullanımını araştırmıştır. Çalışmada atık seramik tozu oranı \%50’de sabit tutulmuştur. Bunun yanı sıra yüksek firın cürufu yerine \%10,20,30,40 oranlarında uçucu kül kullanılmıştır (Şekil 12). Yapılar deneylerle uçucu külün içeriğinin artmasıyla harcın dayanıklılığının arttığı gözlenmiştir. Ayrıca dayanımın artmasının yanı sıra uçucu külün kullanılmasıyla enerji tüketiminin, maliyetin ve $\mathrm{CO}_{2}$ salımının azaldığı ortaya konulmuştur (Fahim et al., 2019a). Başka bir çalışmada ise, alkali harçlara seramik tozunun etkisi incelenmiştir. Çalışmada uçucu kül, yüksek firın cürufu ve seramik tozu kullanılmıştır. Numunelerde seramik tozu \%50, 60 ve 70 gibi yüksek oranlarda tutulmuş ve yapılan deneylerle seramik tozunun, uçucu kül ve yüksek fırın cürufuyla birleştirilmesinin alkali harçların işlenebilirliğini arttırdığı görülmüştür. \%50 ve \%70 seramik tozunun kullanıldığ numunelerin kabul edilebilir basınç dayanımı gösterdiği sonucuna ulaşılmış ve en optimum basınç dayanımının ise \%50 seramik tozu, \%40 yüksek fırın cürufu, \%10 uçucu kül içeren numunede olduğu tespit edilmiştir (Fahim et al., 2019b). Seramik tozu ikameli harçların daha sürdürülebilir olduğunu ortaya koyan bir diğer çalışma ise Shoaei vd. (2019)'nin çalışmasıdır. Bu çalışmada atık seramik tozuna dayalı jeopolimer harçların alkali çözelti ve bağlayıcı oranı araştırılmıştır. Elde edilen sonuçlarla seramik tozunun portland çimentolu harçlara uygun bir ikame maddesi olabileceği ortaya konulmuştur (Shoaei et al., 2019). 


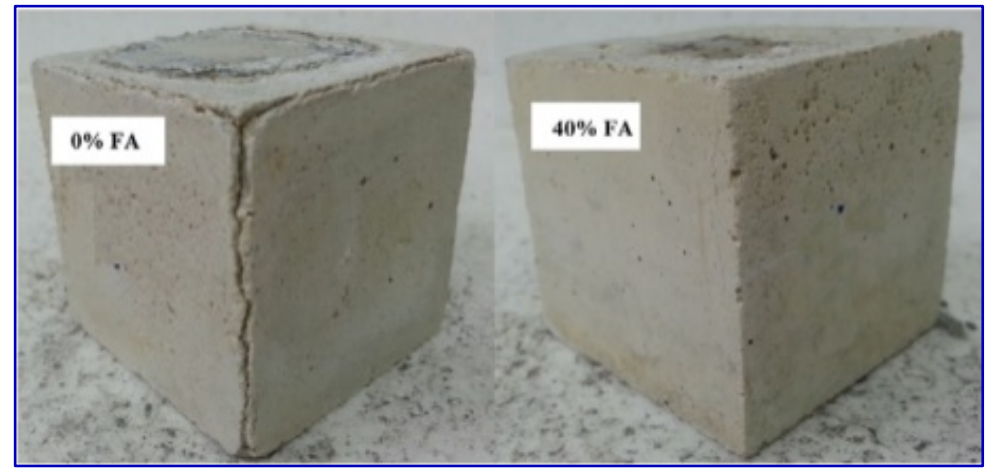

Şekil 12. Farklı oranlarda uçucu kül ile üretilen numuneler (Fahim et al., 2019a).

Seramik atıklarının bir diğer geri dönüşüm yöntemi ise agrega olarak betona katılmasıdır. İri agrega şeklinde betona katılabilen seramik atıklar yapısal olmayan beton uygulamalarında kullanılabilmektedir. Ayrıca seramik agrega katkılı betonun mekanik özelliklerinin geleneksel betona göre daha değişken olduğu bilinmekte ve kullanılan seramik tipi de betonun mekanik özelliklerine etki etmektedir. Bu nedenle yüksek oranda gözenekli atık seramiklerin betonda kullanılabilmesi için ön ıslatma işlemi yapılması gerekmektedir (Anderson et al., 2016). Kaba agreganın betona katılmasıyla ilgili yapılan bir çalışmada (Şekil 13), agreganın betonun davranışına olumsuz bir etkide bulunmadığı ve karışımda basınç dayanım performansı için en uygun oranın $\% 10$ ile $\% 30$ arasında olduğunu belirtilmiştir (Daniyal and Ahmad, 2007). Buna karşın başka bir çalışma ise beton içinde optimum iri agrega kullanımının \%15 olması gerektiğini belirtmektedir (Sekar, 2017).

Seramik agreganın silis içeriğinden ötürü doğal agrega performansını karşılayabileceği bilinmektedir. İnce seramik agreganın su emme oranının fazla olmasına rağmen nehir kumu yerine betona katılabilmesi de öneriler arasindadır (Awoyera et al., 2017).

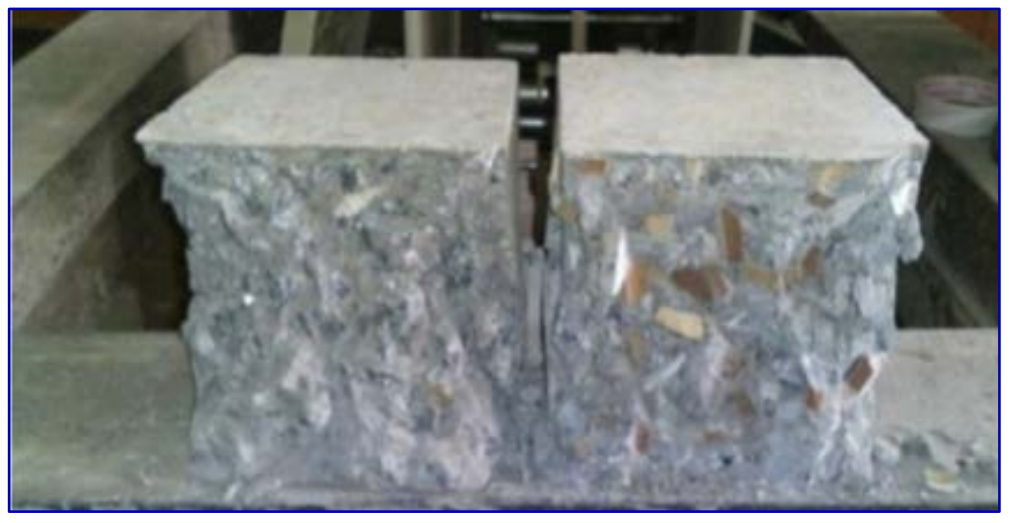

Şekil 13. Seramik agregalı beton numunesi (Daniyal and Ahmad, 2007).

Atık seramik agregaların kendiliğinden yerleşen betona eklendiğinde $\% 50$ ve daha fazla oranda eklenen seramik tozunun yeterli akış, geçme yeteneği ve segregasyon sonuçları verdiği, fakat seramik tozunun artmasıyla akış ve geçme kabiliyeti artmaktayken, ayrışma direncinin azaldığı belirtilmektedir (Huseien et al., 2020).

Atık seramiklerin bir başka geri dönüştürme yöntemi ise asfaltta agrega olarak kullanılabilmesidir. Asfaltta \%40 oranında atık seramik kullanımının statik ve dinamik sünme açısından en iyi performansı verdiği ve Türk Karayolu Yapım Standartları'na göre gereken şartları doğal agreganın \%30’u kadar kullanılan seramik tozunun karşıladığ verebileceğinin altı çizilmektedir (Kara and Karacasu, 2017). Seramik atıklarının asfaltta kullanımının asfaltın soyulma direncine etkisine yönelik yapılan çalışmada; doğal agrega ile oluşturulan asfaltla farklı yüzdelerde seramik agrega kullanılan numuneler karşılaştıııldığında, \%20 oranında seramik atığı kullanılan numunenin doğal agreganın performansına eriştiği görülmektedir (Öner, 2020).

Seramik agreganın asfaltta kullanılabilirliğinin yanı sıra yol alt zemin tasarımında kullanımı da araştııılmıştır. Yapılan çalışmada ağırlıkça farklı oranlarda kullanılan seramik atıklarının karşılaştıııldığı numunelerde, seramik katkısının taşıma oranını arttırdığı, basınç dayanımını ise düşürdüğü sonucuna ulaşılımıştır. Kullanılan seramik 
oranının artmasıyla birim ağırlığın arttığı, su içeriği ve boşluk oranının azaldığı gözlenmiştir. Boşluktaki azalmanın sıkıştırılma değerini de azaltması ve seramik ikamesinin taşıma oranını arttırması gibi avantajlar ile otoyol kaplamasının tasarım kalınlığında önemli bir azalma sağlanabileceği öngörülmüştür (Cabalar et al., 2017). Seramik atıkları su ile temas ettiğinde önemli oranda genişleyen toprakların stabilizasyonunda kullanılabilmektedir. Atık seramik tozu ilavesi ile kuru yoğunluk artış ve nem miktarı ise azaldığından, özellikle \%30 oranında seramik tozu ilavesiyle esnek alt tabanın güçlendirilebileceğine yönelik çalışmalar mevcuttur (Sabat, 2012; Upadhyay and Kaur, 2016, 2021). Atık seramiklerin betonda kullanımı ile atık camların betonda kullanımı karşılaştırıldığında elde edilen seramik katkılı betonun basınç ve eğilme dayanımı açısından cam katkılı betona göre daha iyi performansa sahip olduğu bilinmektedir (Sekar et al., 2011).

Tablo 6. Atık seramik için geri dönüşüm önerileri.

\begin{tabular}{|c|c|c|}
\hline Geri dönüşüm önerisi & Boyutu & Çalıșmalar \\
\hline $\begin{array}{l}\text { Betonda katkı maddesi olarak } \\
\text { kullanımı }\end{array}$ & $\begin{array}{l}\text { İri ve ince } \\
\text { agrega }\end{array}$ & $\begin{array}{l}\text { (Anderson et al., 2016), (Awoyera et al., } \\
\text { 2017), (Daniyal and Ahmad, 2007), (Sekar, } \\
\text { 2017), (Sekar et al., 2011) }\end{array}$ \\
\hline $\begin{array}{l}\text { Kendiliğinden yerleşen betonda } \\
\text { kullanımı }\end{array}$ & İnce agrega & (Huseien et al., 2020) \\
\hline $\begin{array}{l}\text { Çimento katkı maddesi olarak } \\
\text { kullanımı }\end{array}$ & İnce agrega & (Ünal, 1998), (Kalınçimen vd., 2015) \\
\hline $\begin{array}{l}\text { Harç katkı maddesi olarak } \\
\text { kullanımı }\end{array}$ & İnce agrega & $\begin{array}{l}\text { (Hasanah et al., 2018), (Fahim et al., 2019a), } \\
\text { (Fahim et al., 2019b), (Shoaei et al., 2019) }\end{array}$ \\
\hline $\begin{array}{l}\text { Yol alt temel malzemesi olarak } \\
\text { kullanımı }\end{array}$ & İri agrega & (Cabalar et al., 2017) \\
\hline Asfaltta kullanımı & İri agrega & and Karacasu, 2017), (Öner, 2020) \\
\hline Toprak stabilizasyonunda kullanımı & İnce agrega & (Sabat, 2012), (Upadhyay and Kaur, 2016) \\
\hline
\end{tabular}

Yukarıda belirtilen çalışmalar bağlamında atık seramiklerin betona ve çimentoya katkı maddesi olarak, yol alt temel yapımında ve asfaltta, kendiliğinden yerleşen betona katkı maddesi olarak ve toprak stabilizasyonunda kullanılabileceği sonucuna ulaşılmıştır. Bu öneriler için uygun tane boyutları Tablo 6'da verilmiştir. Eğitim yapısında geri dönüşüm yerine atık sahalarına terkedilen seramik atıkları için bu öneriler atık tuğlada da olduğu gibi kolaylıkla uygulanabilecek durumdadır.

\subsection{Engellenebilecek Gömülü Karbon Miktarı}

Tuğla ve seramik atıklarının atık sahalarına gönderilmeyip geri dönüştürülmesiyle, yeni kaynak kullanımının önüne geçilebileceği ve böylelikle aynı malzemenin yeniden üretilmesiyle oluşacak yeni karbon salımlarının engellenebileceği açıktır. Bölüm 3.1. ve Tablo 4’te görülebileceği gibi yaklaşık olarak $1393 \mathrm{~m}^{2}$ tuğla ve $960 \mathrm{~m}^{2}$ seramik atık sahalarına nakledilmiştir. Bu atıkların geri dönüşümü ile engellenebilecek gömülü karbon değeri Eş. 1 yardımıyla hesaplanmış ve Tablo 7'de verilmiştir. Bu bağlamda, tuğla için 220 601,052 kgCO 2 eq yani 220 ton $601 \mathrm{kgCO}_{2} \mathrm{eq}$, seramik için ise $8041,973 \mathrm{kgCO}_{2} \mathrm{eq} / 8$ ton $41 \mathrm{kgCO}_{2}$ eq'nin doğaya salımı engellenebilmektedir. $\mathrm{Bu}$ rakamlar kentsel dönüşümle yıkılan yapılarımızdan, elde edilen atık kazanımı ile büyük miktarda önüne geçebileceğimiz kaynak kullanımı ve karbon salımı anlamına gelmektedir. Sadece bu yapıda salımı engellenebilecek karbon miktarı 10887 ağacın 1 yıllık soğurabileceği $\mathrm{CO}_{2}$ miktarına eşittir (URL 6).

Tablo 7. Malzemelerin engellenebilecek gömülü karbon değerleri.

\begin{tabular}{llllll}
\hline $\begin{array}{l}\text { Yıkıntı } \\
\text { Atığı }\end{array}$ & $\begin{array}{l}\mathbf{1 ~ m}^{\mathbf{2}} \text { 'deki } \\
\text { Adedi }\end{array}$ & $\begin{array}{l}\text { Kullanılan } \\
\text { toplam } \mathbf{m}^{2}\end{array}$ & $\begin{array}{l}\text { Yapıdaki } \\
\text { toplam ağırlık } \\
\text { (kg) }\end{array}$ & $\begin{array}{l}\text { Gömülü } \\
\text { karbon değeri } \\
\text { (kgCO2eq) }\end{array}$ & $\begin{array}{l}\text { Toplam gömülü } \\
\text { karbon değeri } \\
\text { (kgCO2eq) }\end{array}$ \\
\hline $\begin{array}{l}\text { Tuğla } \\
\text { Seramik }\end{array}$ & 166 & 1393 & 490224,560 & 0.45 & 220601,052 \\
\hline
\end{tabular}

\section{Sonuç ve Öneriler}

İnşaat sektörü hammadde kullanımının en fazla olduğu sektörlerdendir. Bir malzemenin oluşum enerjisi onun çıkarılıp, işlenmesine kadar adımlardaki harcanan enerjiyi içermektedir. Bu hammaddeler kullanıma hazır hale gelene kadar birçok işlemden geçmekte ve her bir işlem kaynak girdisini gerektirmektedir. Bu nedenle, hammadde 
girdisinin yoğun olduğu sektörde, kaynak ve enerji kullanımının azaltılması için geri dönüşüm ve yeniden kullanım yöntemleri atık yönetimi bağlamında oldukça önemlidir.

Ülkemizde atık yönetimi sınırlı kalmakta ve genellikle hurda değeri yüksek malzemelerin geri dönüşümüne önem verilmektedir. Hurda değeri yüksek malzeme miktarının kısıtlı olması, dolgu duvar malzemesi ya da zemin kaplama malzemesi gibi yüzeysel anlamda büyük yer tutan ve buna bağlı olarak da yüksek miktarda atığa sebep olan bu malzemelerin geri kazanımı önemlidir. Tŭgla ve seramik atıklarına yönelik yapılan literatür çalışmaları incelendiğinde çok fazla işleme gerek duyulmadan ince ya da iri agrega olarak betonda, asfaltta, kaldırımda ve çimentoya katkı maddesi gibi birçok alanda kullanımının mümkün olduğu görülmektedir. Bu bağlamda bu yıkıntı atıklarının geri dönüştürülmesi ile yeni kaynak kullanımının önüne geçilebilecek ve aynı malzemenin yeniden üretiminin engellenmesi ile tuğla için yaklaşık 220 ton seramik için de 8 ton civarında bir karbon salımının önüne geçilebilecektir. Karbon salımı ile doğru orantılı olarak yüksek miktarda enerji ihtiyacı da azaltılmış olacaktır. Ayrıca çevre kirliliklerinin önüne geçilebilecek, havanın, toprağın ve suyun kirlenmesi engellenebilecektir.

Tüm bu veriler dikkate alındığında yapı tasarım evresinden başlayan malzeme ve kaynak korunumunun, yapının yıkım evresi ve yıkım sonrası evresinde de devam etmesi, buna bağlı olarak yapının uygulama projesinin yanında, yapının yıkım yönteminden yapı bileşenlerinin geri kazanım yöntemlerinin planlandı̆̆ı yıkım projesinin de oluşturulması sürdürülebilir ve yaşanabilir çevrelerin oluşturulmasında önemli bir adım olarak görülmektedir.

\section{Teşekkür}

Bu araştırma, kamu, ticari veya kâr amacı gütmeyen sektörlerdeki finansman kuruluşlarından belirli bir hibe almadi.

\section{Kaynaklar}

1. Abed, A., Mahdi, Z. (2018). Study of Using the Crushed Clay Bricks With Natural Aggregate As Unbound Subbase Pavement Layer in Segregated Form. Al-Qadisiyah Journal for Engineering Sciences, 10(4), 496504.

2. Açıkgenç, M. (2009). Tuğla Ve Kiremit Atıklarının Kendiliğinden Yerleşen Harcın Mühendislik Özelliklerine Etkisi. Yüksek Lisans Tezi (yayımlanmış),Fırat Üniversitesi Fen Bilimleri Enstitüsü,Elazı̆̆, $80 \mathrm{~s}$.

3. Al-Ansary, M. S., El-Haggar, S. M., Taha, M. A. (2004). Sustainable Guidelines For Managing Demolition Waste in Egypt. International Rllem Conference On The Use Of Recycled Materials in Buildings and Structures, 8 -11 November, 335-561.

4. Anderson, D. J., Smith, S. T., Au, F. T. K. (2016). Mechanical properties of concrete utilising waste ceramic as coarse aggregate. Construction and Building Materials, 117, 20-28.

5. Atık Çerçeve Direktifi, 2008 (2008/98/EC). http: https://eurlex.europa.eu/LexUriServ/LexUriServ.do?uri=OJ:L:2008:312:0003:0030:EN:PDF Erişim tarihi: 09.06.2021

6. Awoyera, P. O., Akinmusuru, J. O., Ndambuki, J. M., Lucas, S. S. (2017). Benefits of using ceramic tile waste for making sustainable concrete. Journal of Solid Waste Technology and Management, 43(3), 233-241.

7. Aydın İpekçi, C., Coşkun, N., Tıkansak Karadayı, T. (2017). İnşaat Sektöründe Geri Kazanılmış Malzeme Kullanımının Sürdürülebilirlik Açısından Önemi. TÜBAV Bilim, 10 (2), 43-50.

8. Bektas, F., Wang, K., Ceylan, H. (2009). Effects of crushed clay brick aggregate on mortar durability. Construction and Building Materials, 23(5), 1909-1914.

9. Bektaş, F. (2014). Alkali reactivity of crushed clay brick aggregate. Construction and Building Materials, 52, 79-85.

10. Bolouri Bazaz, J., Khayati, M. (2012). Properties and Performance of Concrete Made with Recycled LowQuality Crushed Brick. Journal of Materials in Civil Engineering, 24(4), 330-338.

11. Buzkan, C., Erman, O. (2019). Yapısal Atıkların Geri Dönüşüm Sorunu ve Türkiye'deki Durumun Mevzuat Bakımından Değerlendirilmesi. Doğal Afetler ve Çevre Dergisi, 90(432), 1-12.

12. Cabalar, A. F., Hassan, D. I., Abdulnafaa, M. D. (2017). Use of waste ceramic tiles for road pavement subgrade. Road Materials and Pavement Design, 18(4), 882-896.

13. Cachim, P. B. (2009). Mechanical properties of brick aggregate concrete. Construction and Building Materials, 23(3), 1292-1297.

14. Chen, M. Z., Lin, J. T., Wu, S. P., Liu, C. H. (2011). Utilization of recycled brick powder as alternative filler in asphalt mixture. Construction and Building Materials, 25(4), 1532-1536. 
15. Çakar B. (2009). Esnek Üst Yapılarda Tuğla Kırığı Atıkları Kullanımının Deneysel Olarak İrdelenmesi. Yüksek Lisans Tezi (yayımlanmış), Eskişehir Osmangazi Üniversitesi Fen Bilimleri Enstitüsü, Eskişehir,112 s.

16. Dalkılıç S. (2014). Tuğla Tozu Katkılı Harçlarda Donatı Korozyonunun Araştırılması. Yüksek Lisans Tezi (yayımlanmış),Süleyman Demirel Üniversitesi Fen Bilimleri Enstitüsü, Isparta, 145 s.

17. Daniyal, M., Ahmad, S. (2007). Application of Waste Ceramic Tile Aggregates in Concrete. International Journal of Innovative Research in Science, Engineering and Technology ( An ISO Certified Organization), 3297(12), 12808-12815.

18. Debieb, F., Kenai, S. (2008). The use of coarse and fine crushed bricks as aggregate in concrete. Construction and Building Materials, 22(5), 886-893.7

19. Demir, I., Orhan, M. (2003). Reuse of waste bricks in the production line. Building and Environment, 38(12), 1451-1455.

20. European Commission Energy Department (2021) "In focus: Energy efficiency in buildings", [pdf] Energy Department, Brussels, Available at:

https://ec.europa.eu/info/sites/default/files/energy_climate_change_environment/events/documents/in_foc us_energy_efficiency_in_buildings_en.pdf [Erişim tarihi: 15.01.2021]

21. Fahim, G., Rahman, A., Sam, M., Wei, K., Mirza, J., Tahir, M. (2019a). Evaluation of alkali-activated mortars containing high volume waste ceramic powder and fly ash replacing GBFS. Construction and Building Materials, 210, 78-92.

22. Fahim, G., Rahman, A., Sam, M., Wei, K., Ali, M., Tahir, M., Mirza, J. (2019b). Properties of ceramic tile waste based alkali-activated mortars incorporating GBFS and fly ash. Construction and Building Materials, 214, 355-368.

23. Fırat, F. K., Akbaş, F. (2015). İnşaat Endüstrisinde Geri Dönüşüm Çalışmalarının Geliştirilmesi ve Ekonomi Üzerine Etkileri. Internatıonal Conference On Eurasıan Economıes 2015, 637-644.

24. Fort, J., Cerny, R. (2020). Transition to circular economy in the construction industry: Environmental aspects of waste brick recycling scenarios. Waste Management, 118, 510-520.

25. Gündüz, B., \& Dönmez, Y. (2018). Üniversite Çalışanlarının Ekoturizm Algısı. Bartın Orman Fakültesi Dergisi, 20(2), 152-162.

26. Hasanah, N., Shukor, A., Hossein, L., Rahman, A., Sam, M., Tahir, M., Samadi, M. (2018). Microstructure and Strength Properties of Mortar Containing Waste Ceramic Nanoparticles. Arabian Journal for Science and Engineering, 43(10), 5305-5313.

27. Huseien, G. F., Sam, A. R. M., Shah, K. W., Mirza, J. (2020). Effects of ceramic tile powder waste on properties of self-compacted alkali-activated concrete. Construction and Building Materials, 236, 117574.

28. Islam, R., Nazifa, T. H., Yuniarto, A., Shanawaz Uddin, A. S. M., Salmiati, S., Shahid, S. (2019). An empirical study of construction and demolition waste generation and implication of recycling. Waste Management, 95, 10-21.

29. İyican, A. B. (2016). İlk, Orta, Lise Binalarının Eğitim Yapıları Asgari Tasarım Standartları Kılavuzunda Yer Alan Yönlenme İlkeleri Açısından Değerlendirilmesi : Karabük Örneği. Yüksek Lisans Tezi (yayımlanmış),Karabük Üniversitesi Fen Bilimleri Enstitüsü, Karabük, 136 s.

30. Jankovic, K., Nikolic, D., Bojovic, D. (2012). Concrete paving blocks and flags made with crushed brick as aggregate. Construction and Building Materials, 28(1), 659-663.

31. Kalınçimen, G., Öztürk, A. U., Kaplan, G., Yıldızel, S. A. (2015). Seramik Atıklarının Çimento İkame Malzemesi Olarak Kullanılması ve Asit Dayanıklılığının İncelenmesi. Kastamonu University Journal of Engineering and Sciences, 1(1), 9-16.

32. Kara, Ç., Karacasu, M. (2017). Investigation of waste ceramic tile additive in hot mix asphalt using fuzzy logic approach. Construction and Building Materials, 141, 598-607.

33. Kılıç, N. (2012). Kentsel Dönüşümde Geri Dönüşüm Atığı. Ar\&ge Bülten 2012 Aralk-Sektörel, 12-20.

34. Kotan S. (2016). Yıkım işlemleri ve Hafriyat Toprağı ile İnşaat ve Yıkıntı Atıklarının Kontrolü Yönetmeliği taslağ1, Yaşanabilir Çevreler ve Marka Şehirler, Hedef 2023, Demolition Conference İstanbul, Turkey.

35. Kumanayake, R., Luo, H. (2018). A tool for assessing life cycle $\mathrm{CO}_{2}$ emissions of buildings in Sri Lanka. Building and Environment, 128(November 2017), 272-286.

36. Külekçi G (2013). Mermer Ve Tuğla Atıklarının Macun Dolguda Kullanılabilirliğinin Araştırılması. Yüksek Lisans Tezi (yayımlanmış),Karadeniz Teknik Üniversitesi Fen Bilimleri Enstitüsü, Trabzon, 86 s.

37. Li, H., Dong, L., Jiang, Z., Yang, X., Yang, Z. (2016). Study on utilization of red brick waste powder in the production of cement-based red decorative plaster for walls. Journal of Cleaner Production, 133, 10171026.

38. Ma, Z., Tang, Q., Wu, H., Xu, J., Liang, C. (2020). Mechanical properties and water absorption of cement composites with various fineness and contents of waste brick powder from C\&D waste. Cement and Concrete Composites, 114(April), 103758. 
39. Maçin, K. E., Demir, İ. (2018). Kentsel Dönüşüm Sürecinde İstanbul'da İnşaat ve Yıkıntı Atıkları Yönetimi. Adlyaman Üniversitesi Mühendislik Bilimleri Dergisi, 9, 188-201.

40. Meza, A., Siddique, S. (2019). Effect of aspect ratio and dosage on the flexural response of FRC with recycled fiber. Construction and Building Materials, 213, 286-291.

41. Mohammadinia, A., Arulrajah, A., Horpibulsuk, S., Chinkulkijniwat, A. (2017). Effect of fly ash on properties of crushed brick and reclaimed asphalt in pavement base/subbase applications. Journal of Hazardous Materials, 321, 547-556.

42. Ortega, J. M., Letelier, V., Solas, C., Moriconi, G., Climent, M. A., Sanchez, I. (2018). Long-term effects of waste brick powder addition in the microstructure and service properties of mortars. Construction and Building Materials, 182, 691-702.

43. Ölmez, E., Yıldız, Ş. (2008). İnşaat ve Yıkıntı Atıklarının Yönetimi ve Planlanan İstanbul Modeli. Kent Yönetimi, İnsan ve Çevre Sorunları 08 Sempozyumu, 02-06 Kasım 2008.

44. Öner, J. (2020). Seramik Atıklarıyla Hazırlanan Asfalt Karışımların Soyulmaya Karşı Dayanımının Belirlenmesi. Afyon Kocatepe Üniversitesi Fen ve Mühendislik Bilimleri Dergisi, 20, 498-505.

45. Özyavuz, M., \& Dönmez, Y. (2016). Konut ve Site Alanlarında Uygulanan Peyzaj Tasarımlarının Yeterliliği Üzerine Bir Araştırma: Tekirdağ Kenti. Düzce Üniversitesi Ormancılık Dergisi, 12(2), 108-122.

46. Paker, B. (2017). Sürdürülebilir Bina Üretiminde Mimarın Yapısal Atık Oluşumuna Bakış Açısının İncelenmesi: Bursa Alan Çalışması. Yüksek Lisans Tezi (yayımlanmış),Uludağ Üniversitesi Fen Bilimleri Enstitüsü, Bursa, 129 s.

47. Poon, C. S., Chan, D. (2006a). Paving blocks made with recycled concrete aggregate and crushed clay brick. Construction and Building Materials, 20(8), 569-577.

48. Poon, C. S., Chan, D. (2006b). Feasible use of recycled concrete aggregates and crushed clay brick as unbound road sub-base. Construction and Building Materials, 20(8), 578-585.

49. Robati, M., Oldfield, P., Akbar, A., Carmichael, D. G., Kuru, A. (2021). Carbon value engineering : A framework for integrating embodied carbon and cost reduction strategies in building design. Building and Environment, 192(October 2020), 107620.

50. Sabat, A. K. (2012). Stabilization of expansive soil using waste ceramic dust. Electronic Journal of Geotechnical Engineering, 17, 3915-3926.

51. Sabbas, T., Polettini, A., Pomi, R., Astrup, T., Hjelmar, O., Mostbauer, P., Cappai, G., Magel, G., Salhofer, S., Speiser, C., Heuss-Assbichler, S., Klein, R., Lechner, P. (2003). Management of municipal solid waste incineration residues. Waste Management, 23(1), 61-88.

52. Saleem, B., Hussain, A., Khattak, A., Khan, A. (2021). Performance evaluation of bacterial self-healing rigid pavement by incorporating recycled brick aggregate. Cement and Concrete Composites, 117, 103914.

53. Sapmaz Veral, E., Yiğitbaşıŏlu, H. (2018). Avrupa Birliği Atık Politikasında Atık Yönetiminden Kaynak Yönetimi Yaklaşımına Geçiş Yönelimleri ve Döngüsel Ekonomi Modeli.Ankara Üniversitesi Çevrebilimleri Dergisi, 6(1), 1-19.

54. Sekar, M. (2017). Partial Replacement of Coarse Aggregate by Waste Ceramic Tile in Concrete. International Journal for Research in Applied Science and Engineering Technology, V(III), 472-479.

55. Sekar, T., Ganesan, N., Nampoothiri, N. (2011). Studies on Strength Characteristics on Utilization of Waste Materials as Coarse Aggregate in Concrete. International Journal of Engineering Science and Technology (IJEST), 3(7), 5436-5440.

56. Sev, A. (2009). Sürdürülebilir Mimarlık. YEM Yayın. İstanbul. ISBN: 9789944757225

57. Shoaei, P., Reza, H., Mirlohi, F., Narimani, S., Ameri, F. (2019). Waste ceramic powder-based geopolymer mortars : Effect of curing temperature and alkaline solution-to-binder ratio. Construction and Building Materials, 227, 116686.

58. Soysal, S. (2008). Konut Binalarında Tasarım Parametreleri ile Enerji Tüketim İlişkisi. Yüksek Lisans Tezi (yayımlanmış),Gazi Üniversitesi Fen Bilimleri Enstitüsü, Mimarlık Anabilim Dalı, 145 s.

59. Tuna Kayıl, M., Özmen, S. T. (2020). Determining of the embodied carbon of light gauge steel and wood wall construction. El-Cezeri Journal of Science and Engineering, 7(2), 603-618.

60. Tuna Kayılı, M., Veer, F. A., Çelebi, G. (2016). Assessment of the energy savings and $\mathrm{CO}_{2}$ emissions reduction of glass structures through alternative demolition scenarios. Glass Structures and Engineering, $1(2), 435-449$.

61. Upadhyay, A., Kaur, S. (2016). Review on Soil Stabilization Using Ceramic Waste. International Research Journal of Engineering and Technology, 3(7), 1748-1750.

62. URL-1 (2021).https://webdosya.csb.gov.tr/db/afyon/menu/sifir-atik-02_20180403035822.pdf

63. URL-2 (2021).https://ced.csb.gov.tr/2019-yili-il-cevre-durum-raporlar-i-98681

64. URL-3 (2021).http://safranbolu.meb.gov.tr/meb_iys_dosyalar/2020_05/29154252_ihale_ilan.pdf

65. URL-4 (2021).

https://h3.googleusercontent.com/proxy/ENZhLRF_fwd9Yh1cnRuirH1v0rC2Gb6CpjzRnmmEw5k1F1Ia -720uS7z83O-IcAPufHQrI5CrR9r4j2eXgw_zFLDRDasQupBPzhNn-5LYgxbwh34Lg 
66. URL-5 (2021).ICE DB V3.0 - 1 Nov 2019 https://circularecology.com/embodied-carbon-footprintdatabase.html (01.03.2021)

67. URL-6 (2021) https://www.viessmann.co.uk/heating-advice/how-much-co2-does-tree-absorb

68. Ünal M., 1998. Atık Seramik Karolarının Çimento Üretiminde Kullanılması. Yüksek Lisans Tezi (yayımlanmış),Anadolu Üniversitesi Fen Bilimleri Enstitüsü, Eskişehir, 82 s.

69. Youssef, N., Rabenantoandro, A. Z., Dakhli, Z., Chapiseau, C., Waendendries, F., Hage Chehade, F., Lafhaj, Z. (2019). Reuse of waste bricks: a new generation of geopolymer bricks. SN Applied Sciences, 1(10), 1-10.

70. Yüksek, I., Mıhlayanlar, E. (2015). Yaşam Döngüsü sürecinde yapı malzemesi çevre etkileşimi. 2.Nd International Sustainable Buildings Symposium, 28-30 May, 975-983.

71. Zawrah, M. F., Gado, R. A., Feltin, N., Ducourtieux, S., Devoille, L. (2016). Recycling and utilization assessment of waste fired clay bricks (Grog) with granulated blast-furnace slag for geopolymer production. Process Safety and Environmental Protection, 103, 237-251.

72. Zhang, S., He, P., Niu, L. (2020). Mechanical properties and permeability of fiber-reinforced concrete with recycled aggregate made from waste clay brick. Journal of Cleaner Production, 268, 121690. 